\title{
Phonological Interference in Reciting Al-Qur'an: A Critical Reflection on the Learning of Al- Qur'an Phonology through Action Research
}

\author{
Tedi Supriyadi 1 \\ Universitas Pendidikan Indonesia \\ Bandung, Indonesia \\ J. Julia and Prana Dwija Iswara \\ Universitas Pendidikan Indonesia \\ Bandung, Indonesia
}

\begin{abstract}
In reciting Al-Qur'an, one is obliged to follow the rules of recitation in order to avoid mistakes in reciting it, both major errors (Lahn Jali) or minor errors (Lahn Khafi). This study aims at analyzing phonological interference in the practice of reciting Al-Qur'an in one of the universities in Indonesia. The method used was action research involving 25 students as the subject, consisting of 12 female and 13 male students. The research subject was a group of people who used Javanese as their native language or have a Javanese cultural background. The techniques of collecting data were listening, documenting, and interviewing. This study produced a number of steps as an act of critical reflection in minimizing the forms of phonological interference in reciting Al-Qur'an, namely Listening, Observation, Verification, Values, and Evaluation (LOVVE) as a learning method. These steps were able to reduce the number of phonological interference in the practice of reciting $\mathrm{Al}$ Qur'an or in other words they were able to increase students' fluency in reciting Al-Qur'an for a total of 24 people (96\%). In conclusion, there were five steps to improve fluency or minimize the form of phonological interference in reading the Qur'an for students from Javanese cultural background.
\end{abstract}

Keywords: Interference; Phonology; Lahn Jali; Lahn Khafi; AlQur'an Learning.

\footnotetext{
${ }^{1}$ Corresponding author e-mail : tedisupriyadi@upi.edu
} 


\section{Introduction}

Indonesia, as one of the countries with majority Muslims population, is a country that has a variety of local languages in addition to the national language. Dharma (2011) mentions that there were 746 local languages in Indonesia and one of which is Javanese. In linguistic studies, each language has a unique phonological system from other languages. Phonology is one of the sub-disciplines of linguistics that studies language sounds, both sounds that carry meaning (phonetics) and sounds that do not (phonemic)(Lathifah, Syihabuddin, \& Al Farisi, 2018; Suherman, 2016). For the Indonesian Muslim community, including the Javanese community, reciting Al-Qur'an in Arabic is a demand and obligation. In addition to being valuable to the reader, the recitation of Al-Qur'an is always inherent in the shalat (prayer) which is a form of worship to The Creator.

The differences in phonological system between Arabic and Javanese language result in the frequent occurrence of pronunciation changes which occur because there are several phonetic features in Javanese that are not found in Arabic phonetic features so that pronunciation changes occur in several consonants of Arabic. In Weinreich's view, errors in pronunciation occur because of contact between two or more languages that are used interchangeably by a language user, so that the contact has an impact on the existence of code switching, code mixing, interference, and integration (Weinreich, 1979).

The accuracy of pronunciation in a speech is important because it can affect the intended meaning of the speaker. Errors in pronunciation of letters in Arabic can affect semantic meaning. For example, if the word (Qُلْ (kul) then the meaning will change. The word قُ eat'. Therefore, the sound elements in Arabic become very important to learn so that the pronunciation of letters in Arabic is in accordance with the rules of the language itself. To be able to pronounce the sounds of the hijaiyyah letters properly and correctly, it is necessary for every language learner to start studying phonology, because sound is the basis of all languages ( $\mathrm{Mu}^{\prime}$ izzuddin, 2002). Without studying phonology in the learning process, it will naturally result in errors that also affect the semantic meaning (Lathifah et al., 2018).

Regarding the phonological interference issues, this study examined some of the results of previous research to look for the relevance of theory and similar methods as an effort to develop and/or look for gaps that have not been studied by previous researchers. For instance, Muhammad Afif Amrulloh's study entitled "Similarity of Sound in Poetry (a Phonology of Al-Quran to Surah AlAsr)" revealing that the existence of verses in Al-Quran was reflected through the similarity of sound in every last paragraph, which was part of the beauty of Al-Qur'an. Based on Surah Al-Asr, as the object of the study, it was found that the study of similarity of vowels and consonants in Surah Al-Asr reveals the ease in recognizing the beauty of language style of Al-Quran, and makes sound and phonology as the most important things in an utterance and sentence (Amrulloh, 2017). 
Furthermore, Hamzah Pansuri's is entitled "Phonological Interference of Indonesian Speakers in Arabic and Vice Versa (Phonological Contrastive Analysis)". The result revealed that there are several aspects that distinguished phonetic vowels and consonants between Arabic and Indonesian. These differences brought changes in words formation and absorption of words received into each component. Arabic that does not have phonetic vowels [e] and [o] certainly uses its concept of vowels in order to adopt foreign words into Arabic, and vocabularies that do not yet exist, or are not suitable for translation, for example computer. Likewise with phonetic consonants, Arabic is rich in fricative consonants, while Indonesian has nasal consonants that Arabic does not have. This certainly affects the teaching of Arabic with many fricative consonants that Indonesian does not have (Pansuri, 2017).

In line with Pansuri, the study conducted by Lathifah et al. entitled "Analysis of Phonological Mistakes in Arabic Text Reading Skills", with the students as the subject of the study, revealed that the phonological errors of students often occurred during reading activities are in the fricative sound, such as

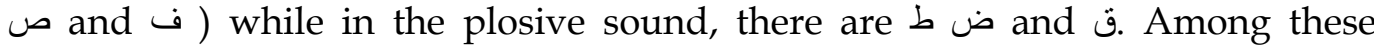
mistakes, the most difficult and most frequent mistakes were in the pronunciation of the letters $\varepsilon$ and ض (Lathifah et al., 2018).

However, these studies of (Pansuri, 2017) and (Lathifah et al., 2018) are still considered global, since they analyzed phonological interferences in people who used the national language(Bahasa Indonesia) as a mother tongue. With 764 indigenous local languages in Indonesia, some Indonesian people did not use Bahasa Indonesia as their mother tongue, but their local languages. According to Wedhawati et.all, (2006 p.1), Javanese language ranked $11^{\text {th }}$ as one of the world's languages with the most speakers. Therefore, this study is focused on examining the phonological interference of Al-Quran uttered by people who spoke Javanese as a mother tongue. Interference was very likely to occur in speaking the sound of Al-Quran by Javanese speakers, because phonological deviations are caused by the first language acquired and used by speakers, so that it affects the pronunciation of other languages, in this case Arabic (Aktürk-Drake, 2010; Hamzah \& Busri, 2015; Khasanah \& Qosim, 2017; Nokman, Mat, Bakar, Musilehat, \& Yaakub, 2017)

Unlike Amrulloh, (2017), study that used Surah Al-Asr as the object of phonological study, this study uses Surah A-Fatihah as the object of study of phonological interference uttered by students. It is considered important, because Surah Al-Fatihah is a part of pillars of Islam (Shalat), which is an mandatory that must be carried out by every adult Muslim, so that in the narration the verses must not be mistaken in uttering, especially if uttering is wrong, it will affect changes in meaning (Taufiqurrochman, 2007)

Based on the aforementioned study results, in an attempt to limit the problems studied, this study intends to answer a number of the research questions, which are formulated as follows: 1) How do the forms of phonological interference in the practice of reading Al-Quran in Surah Al-Fatihah uttered by the Javanese speakers?; 2) What actions can be taken in an effort to minimize interference so that the subject can accurately recite Al-Quran?;3) How does the analysis of the 
results of actions minimize the phonological interference in the reading of AlQuran in Surah Al-Fatihah?

Therefore, the purposes of this study are as follows: 1) To recognize the forms of phonological interference in the practice of reading Al-Quran in Surah AlFatihah uttered by the students; 2) To find the action steps required to minimize phonological interference so that the pronunciation of the Surah in the reading of Al-Quran can be practiced accurately; and 3) To recognize the results of actions in the phonology learning process.

The results of this study are expected to make contribution to the development of the method of learning Al-Quran, especially related to learning the phonology of the Arabic letters. It is very clear that the sound element in Arabic as the language of Al-Quran becomes significant to be learned with the aims of pronouncing Arabic letters in accordance with established rules (Lathifah et al., 2018).

\section{Literature Review}

\subsection{The Phonology of Al-Qur'an}

The importance of Arabic language in the modern world certainly cannot be separated from its position as the language of Al-Qur'an or a religious language. In addition, Arabic is used as the national language in 20 countries including Algeria, Bahrain, Egypt, Eritrea, Iraq, Jordan, Kuwait, Lebanon, Libya, Mauritania, Morocco, Oman, Qatar, Saudi Arabia, Somalia, Sudan, Syria, Tunisia, Yemen, and Palestine. Therefore, Arabic is a Semitic language belonging to the most important Afro-asiatic family (Dalby, 2015 p.25). Additionally, Arabic can be referred to as the language of Islamic religious rituals used by all Muslims all over the world. In the Muslims' view, studying Al-Qur'an in Arabic is an obligation (Shihab, 1992). So whoever wants to learn understanding AlQur'an, inevitably, ones must first know the language, Arabic. To get to know Arabic, ones must learn to recite the sounds and hijaiyyah letters contained therein. Differences in pronunciation can sometimes lead to differences in meaning. Hence, to understand Al-Qur'an, ones must master the principle of tajweed and sounds found in al-ashwat (Adriana, 2017)

People who use Arabic as their first language may not find difficulties. However, people who do not use Arabic as the first language will find difficulties and can lead to errors in language. Language errors are deviations of language rules which are natural symptoms in the second language learning process (Batmang, 2015).

Common language errors are generally related to pronunciation errors that trigger spelling errors. Pronunciation errors are results of the speaker's first language background. Pronunciation errors are closely related to phonological aspects and phonological errors are a form of error that belongs to the linguistic taxonomy. These errors occur at the level of sound at the level of words, phrases, clauses or sentences. Mistakes in phonological aspects occur in the use of spoken language, both in productive (speaking) and receptive (listening) skills. One example of pronunciation errors in Arabic is the word المَطَر (rain) mispronounced as المَطًار (airport) (Lathifah et al., 2018). Therefore, Lodge (2003)argues that 
sounds, especially linguistic sounds, have an effect on any hearer. Furthermore, since Arabic is closely related to Al-Qur'an, studying the sounds of each letter is inevitable. Sai (2018)states that Al-Qur'an is the speech of God, hence, it is the primary reason for exact pronunciation being considered crucial.

Language sounds that affect hearing comes from speech organs. Language sounds demand the placement of speech organs in certain places and they are limited. According to Mu'izzuddin (2002), matters related to the language sounds include four aspects, namely 1) speech organs (Jihazu an-Nutqi جهاز النطق), 2) place of articulation (Makhariju al-Aswativaracteristics (Sifat al-Aswati) including voiced and voiceless or jahrwa hams, plosive and sibilance or syiddah شدة warakhwah رخوة , thick and thin sounds or tafhimwatarqiq, and 4) intonation or tangim تنغيم.

\subsubsection{Sound Instrument}

Sound instruments that play a role in producing language sounds are around the throat, mouth and nose. Nasution (2017 p.72) states, there are 15 instruments that create language sounds, namely:

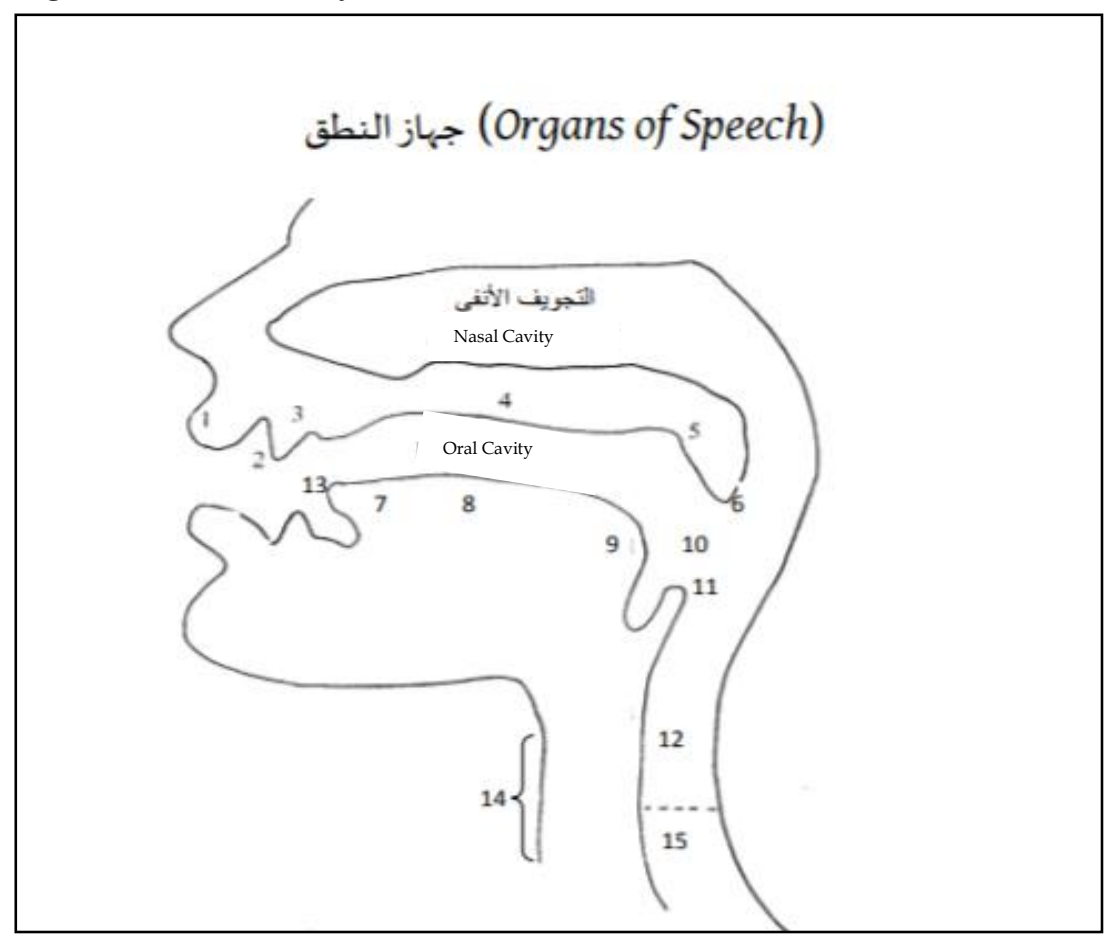

Figure 1 : Organ of Speech (Nasution,2017, p. 73)

1. Lips (الثفاه); 2. Teeth (الأسنان); 3. Teeth-ridge (الأسنان أصول); 4. Hard palate (الحنان)

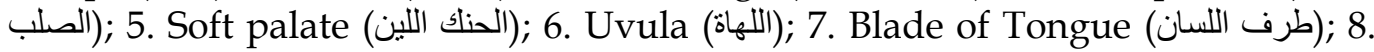
Middle of tongue (وسط اللسان) 9ؤخر اللسان) 9. Back of tongue 10. Pharynx (الحسلق) Epiglottis (المزمار لسان); 12. Position of Vocal Chords (موقع الأوتار الصوتية); 13. Tip of tongue (نهاية اللسان) (الحنجرة); 14. Larynx 15. Windpipe (القصبة الهو ائية).

\subsubsection{Sound Producing Instruments}

Regarding the sound producing instruments of Makhoriju al-Aswati, Mu'izzuddin (2002) divides it into two, namely based on modern Arabic linguists and based on classical linguists. Based on modern Arabic linguists and 
well-known qori in the Arab Republic of Egypt that there are 11 makhorijul aswat in Arabic languages:

1. Lips (Syaffah) including the letters:

2. Teeth with lips (Asnaniyyah Syafawiyah) including the letter: ف

3. In between the upper and lower teeth (ma bainal asnan) including the letters: ظ, ذ,

4. Teeth and gums (Asnaniyyah lisawiyah) including the letters: ض, ط, د, ت

5. Gums (lisawiyah) including the letters: ص, س,j,ر

6. Gums and palate (Lisawiyyah hakiyyah) including the letters: ش, ج

7. Gums and palate (wasatul-hanaki) including the letter:

8. Gums and palate (Aqsal-hanaki) including the letters: و, ك,

9. Phlegm (luhatu) including the letter: ق

10. Throat (khalq) including the letters: $ح, \tau$,

11. Glottal (hanzarah) including the letters: $\bullet, \&$

In addition, according to classical linguists such as Imam Khalil ibn Ahmad, Sibawaih and ibn Jinny, there are fifteen makharijul aswat, namely:

1. In between two lips (Ma Baina Syafataini) including the letters

2. Lower lip and teeth (Asy-Syafatus-Sufla wal Asnan) including the letter: ف

3. Tip of the tongue and teeth (Tarful Lisan wa Atrafus sanaya) including the letters: ظ, ذ,

4. Tip of the tongue and middle teeth (Tarful Lisan Wa Fawiqus Sanaya) including the letters:

5. Tip of the tongue and maxillary teeth (Tarful Lisan wa Usulus-Sanaya) including the letters: ط, د,

6. In between tip of the tongue and middle teeth (Ma baina Tarful Lisan wa Fawiqus-Sanaya) including the letter: ن

7. In between tip of the tongue and inner middle of the tongue (Ma baina Tarful Lisan wa Fawiqus-Sanaya Adkhala fi Zahril Lisan) including the letters: $\lrcorner$

8. Edge of the tongue to the tip (Hafatul-Lisani ila at-Tarfi wa ma fauqoha) including the letter: $J$

9. Edge of the tongue to molar teeth (Awalu Hafatul Lisani Wa Ma Yalihi minal-Adrasi) including the letters: ش, ض (A

10. Center of the tongue and palate (wasatul-hanaki, wa ma yalihi minalhanakil-a'la) including the letters: ي, ج

11. The tongue and upper palate (Muakhorul-lisan wa ma yalihi minal-hanakil$\left.a^{\prime} l a\right)$ including the letters: s]

12. Maxillary teeth and upper palate (Aqsal hanaki wa ma yalihi minal-hanakila'la) including the letter

13. Close throat (Adnal-Halaqi) including the letters: $\dot{\tau}, \dot{\varepsilon}$

14. Middle throat (Wasatul-Hanaki) including the letters: $\tau, \varepsilon$

15. Deep throat (Aqsal-Hanaki) including the letters: $\&, 0$

\subsubsection{Nature of Sound}

According to Mu'izzuddin, (2002), the nature of the sound of letters in Arabic can be categorized into three parts, namely: 


\section{Vibrating and non-vibrating sounds (jahr wa hams)}

Vibrating sound is every sound produced by the vocal cords while the nonvibrating sound is every sound produced without vibrating the vocal cords. The letters that produce vibrating sound are as follows:

$$
\text { ب }
$$

While, the letters that produce non-vibrating sounds are as follows:

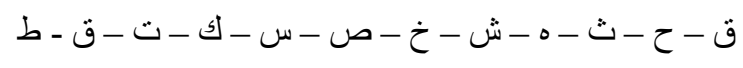

\section{Plosive and fricative sounds (Syiddah Wa rakhwah)}

The indicator of plosive and fricative sounds is indicated based on the air from the lungs being stuck in a certain place so that the air is closed, and eventually cause a burst of air or it comes out along with the pronunciation of certain sounds. The eight letters that produce plosive sound are as follows:

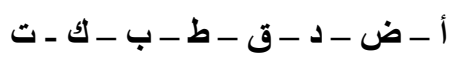

While, the letters produced fricative sounds are as follows:

$$
\text { ه- }
$$

\section{Voiced and voiceless sound (takhim wa tarqiq).}

This sound classification is based on the position of the tongue when pronouncing Arabic sounds. Sounds produced by raising the back of the tongue are called voiced sounds and sounds produced by the flat tongue position are usually called voiceless sound, There are several letters, which have the nature of voiced sounds, including five letters ص - ض- ط- ظ-خ while for other sounds, they are pronounced with tarqiq or voiceless sound.

\subsubsection{Intonation}

Intonation is the high and low sound pressure in a sentence, while the sound pressure in language in words is called stress or nabr in Arabic Mu'izzuddin, (2002). Intonation functions to distinguish the form of positive or negative sentences, narrative or question sentences.

Based on the aforementioned description, Al-Quran, which written in Arabic language, has rules and procedures for reciting it. Therefore, it is very important for everyone, especially a Muslim, to understand phonology in order to be able to read Al-Quran correctly and accurately, Allah (SAW) commands to read AlQuran with tartil, which is in accordance with the Surah Al-Muzzamil, verse 4:

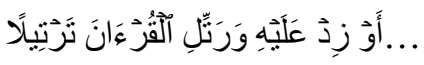

"...Or add to it, and recite Al-Quran with measured recitation (tartil)." (Departemen Agama, 2005) 
Based on the Surah Al-Muzzamil, Verse 4, tartil can also be defined as a way of reading slowly while emphasizing the letters, stopping and starting, so that readers and listeners can understand and appreciate the contents of their messages (Katsir, 2000).

\section{Methods}

This sections elaborates the research design underlying the study, research location and subject, and how the data were collected and analyzed.

\subsection{Research Design}

Research action is the design of this study, since action research has been widely used as a research method in solving problems in the field of education that can be found in various literature (Adelman, 1993; Capobianco \& Feldman, 2006; Jefferson, 2014; Niemi, 2018). In addition, action research provides an opportunity for researchers to find new efforts to make changes that are appropriate to conditions and needs (Darwis, 2016). Using action research, this study explored practical problems to find solutions (Creswell, 2002). The problems in this study are related to phonological interference in the practice of reciting Al-Qur'an which is spoken by speakers whose first language is Javanese. The problems found then became materials for critical reflection in an effort to find a solution by conducting a series of educative actions as an effort to realize new changes in both knowledge, attitude, and practice in pronouncing the letters in the recitation of Al-Qur'an. The solutions found in this study are expected to have a broad impact in solving the same problems in the learning process of Al-Qur'an in other places.

The procedures of the study undertaken in this study refer to the pre-action and post-action phases proposed by Creswell (2002), including: 1) A preliminary study was conducted as pre-action analysis; 2) After the problems have been found and identified, the next step is to design the action steps required, and it will be carried out as an educative action to find solutions to minimize phonological interference; and 3) Critical reflection activities on each step that has been given as a post-action evaluation were conducted. The results of this evaluation are expected to realizing concrete steps for the desired change, so that it is able to become a method that can be applied in overcoming the problem of phonological interference in the practice of reading Al-Quran.

In carrying out research, researchers used collaborative principles, as Creswell (2002) affirms that it is the characteristic of action research design Collaboration in this study involved the researchers as lecturers in the Islamic Religious Education (PAI, Pendidikan Agama Islam) course. One of the lecturers had expertise in the field of music because in a series of actions, especially in the Qur'anic phonology exercises, musical melodies were used. The researchers then collaborated with one of the lecturers who had linguistic expertise as well as lecturers in the field of tafsir(interpretation of meaning) to see whether the phonological interference in the practice of reciting Al-Qur'an conducted by the research subjects had an impact on changes in meaning or not. The researchers then collaborated with one of the student activity units related to Al-Qur'an to be involved in the series of actions. Studies that employed collaborative action research processes in education involve collaboration between teachers, between 
teachers and researchers (Messiou, 2019; Zech, Gause-Vega, Bray, Secules, \& Goldman, 2000).

\subsection{Research Location and Subject}

The participants of this study were students from three batches in a university. The sample consisted of 25 Muslim students who used Javanese as their daily language. They consisted of 15 males and 10 females. The reason for the selection of Javanese language students was that Javanese language, in an estimation in 1999, was spoken by 77.5 million speakers (Wikipedia, 2018) and ranked $11^{\text {th }}$ in the world's languages terms of number of speakers. (Wedhawati et. al, 2006 p.1).

The purposive sampling technique was employed to determine the sample with certain considerations and criteria in accordance with the objectives of the study. The consideration is that every adult Muslim has a mandatory to understand the content of Al-Quran, as the initial gate to understanding Al-Quran. The sample criteria were the students who took classes in Islamic religious education, and speak Javanese as their native language.

\subsection{Data Collection and Analysis}

This study is rich in instruments. Each stage of the action research uses several instruments. First, the pre-action analysis and evaluation stage used survey, pretest, and reading tests, and rubric of phonological interferences as the instruments. The survey was conducted to explore students' experiences and understanding of phonological theory or makhroz in reciting Al-Qur'an by distributing online questionnaires using the Google Form. Pretest was a written test in which students transliterated Arabic into Indonesian by referring to the transliteration of the Ministry of Religious Affairs of Indonesia. Reading test was to observe the practice of reciting Al-Qur'an, which was assessed using the rubric of phonological interference. Second, the critical action and reflection stage used observation, voice recorder, Audacity application, LQT application, and survey as the instruments. Observation was used to identify errors in reciting surah al-Fatihah made by students, which were recorded using Audacity to be analyzed afterward. LQT application was used as supporting material to support the teaching materials during the actions. Survey was done to identify the difficult letters to pronounce and to know students' perspective on the implementation of LQT application in the classroom. Third, the post action and evaluation stage used post-test, survey and interview. Post-test was done to compare the students' progress before and after actions. Survey was done to know students' progress on phonological learning. Interview was used to obtain supporting data and information obtained from survey developed based on the rubric of phonological interference.

These abundant instruments helped the researcher to obtain the validity and reliability of the instruments. According to Fraenkel \& Wallen (2009), validity and reliability can be done by cross-checking source of information between peers and triangulation that involve multiple data resources. This study ensured its validity and reliability by using triangulation and peer-examination done by the researchers. In addition, dependability of finding is seen important as it refers to the consistency and reliability of research findings, and the degree to 
which research procedures are documented (Polit et al., 2006 in Moon et al., 2016). Accordingly, this study has maintained its dependability by documenting the research procedures through some stages using action research, in which each stage showed consistency of findings obtained from different instruments.

The students' recitation of Al-Qur'an was documented by means of recording using Audacity application as shown in Figure 2

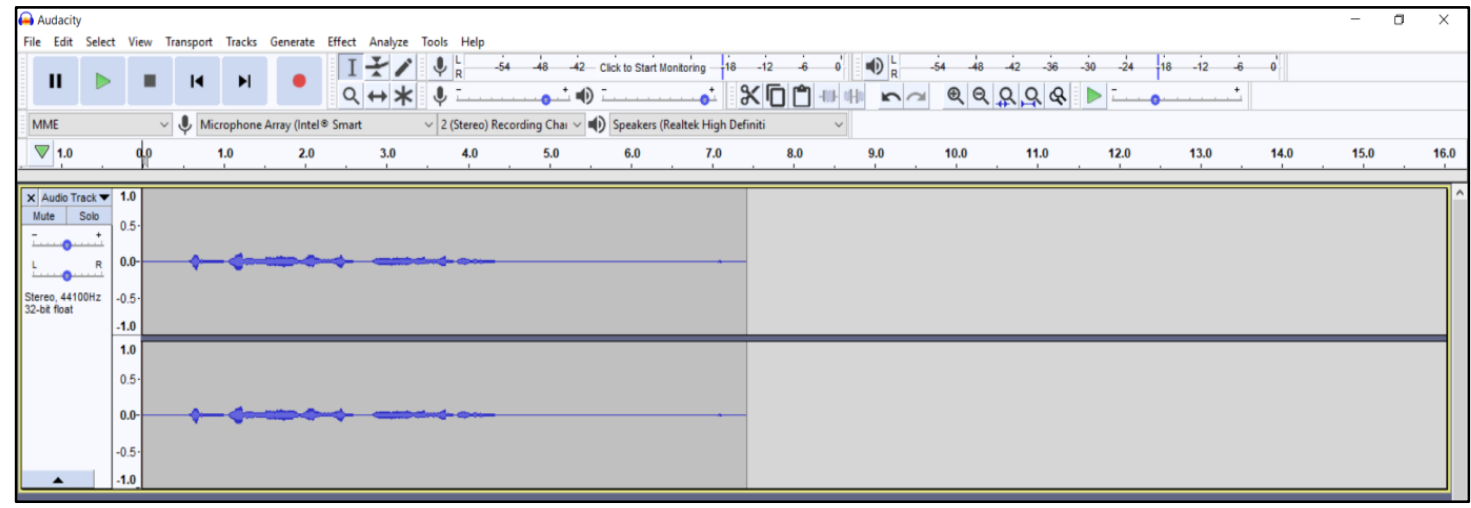

Figure 2. Sound Record Display in Audacity

The test results were then analyzed to find out the forms of phonological interference in the practice of reciting Al-Qur'an spoken by speakers of Javanese as their first language. Furthermore, in this study, semi-structured interviews were conducted to explore opinions about their conditions related to the accuracy in reciting Al-Qur'an and to explore their views after following a series of actions. The last test was the Al-Qur'an reading test conducted during in the pretest and posttest to find out the initial conditions and the final results of the given actions to measure the success rate of the actions in producing a desired change namely the accuracy of students in reciting the hijaiyyah letters (makhroz) in the practice of reciting Al-Qur'an.

\subsection{Development of the Hijaiyyah Phonological Interference Indicators}

To measure the presence or absence of phonological interference in reciting Al-Qur'an, several indicators on the forms of errors were made. The indicators referred to the formulation in tajweed on the forms of errors or deviations that occur in the pronunciation of the verses of the Qur'an or called Lahn (Utsman, 1994). The forms of deviations in reading Al-Qur'an are divided into two parts. The first part is Lahn Jali which is an error that can affect meaning. Second is Lahn Khafi which is an error that does not affect and change meaning. In relation to the form of errors, it was agreed by all ulamas that in the recitation of Al-Qur'an, Lahn Jali is unlawful and Lahn Khafi is makruh (acceptable but not advised) (Taufiqurrochman, 2007). Based on this law, the deviation indicators in reciting Al-Qur'an were formulated and are presented in the following table. 
Table 1. Phonological Interference Indicators

\begin{tabular}{|c|c|c|c|c|}
\hline No & Error (Lahn) & Indicator & Code & $\begin{array}{c}\text { Error } \\
\text { Category }\end{array}$ \\
\hline \multirow{7}{*}{1} & \multirow{7}{*}{ Lahn Jali } & Change of letter with letter & LJ 1 & \multirow{7}{*}{ Major } \\
\hline & & Change of $i^{\prime} r a b$ (harakat, length) & LJ 2 & \\
\hline & & Addition of letter & LJ 3 & \\
\hline & & Elimination of letter & LJ 4 & \\
\hline & & Elimination of tasydid & LJ 5 & \\
\hline & & Addition of tasydid & LJ 5 & \\
\hline & & Elimination of longer letter & LJ 7 & \\
\hline \multirow{5}{*}{2} & \multirow{5}{*}{ Lahn Khafi } & Imperfection in pronouncing harakat & $\begin{array}{l}\text { LK } 1 \\
\end{array}$ & \multirow{5}{*}{ Minor } \\
\hline & & $\begin{array}{l}\text { Addition or reducing the amount of } \\
\text { mad }\end{array}$ & LK 2 & \\
\hline & & $\begin{array}{l}\text { Ignoring ghunnah or addition or } \\
\text { reduction of the amount of ghunnah }\end{array}$ & LK 3 & \\
\hline & & $\begin{array}{l}\text { Excessive vibration (takrir) of the } \\
\text { letter } r a\end{array}$ & LK 4 & \\
\hline & & $\begin{array}{l}\text { Improper thickening (taghlidl) of the } \\
\text { sound lam }\end{array}$ & LK 5 & \\
\hline
\end{tabular}

\section{Results}

This section elaborates the results of the critical reflection on the learning AlQur'an phonology, started from (1) Pre-Action Analysis and Evaluation, (2) Critical Action and Evaluation of the Al-Qur'an Phonological Interference, and (3) Post Action Analysis and Evaluation

\subsection{Pre-Action Analysis and Evaluation}

A total of 25 students who were the research subjects were given survey instruments using the Guttman scale. This survey was administered to find out their experiences and perceptions of how they learned makhroz, the results of their learning, and their subsequent desires related to their accuracy in reciting Al-Quran. The survey results can be seen in Table 2 .

Table 2. Experiences in Learning the Phonology of Al-Qur'an

\begin{tabular}{lcc}
\hline Experiences in Learning Reciting Al-Qur'an & Yes & No \\
\hline Do you know what is makhroz (علم الاصوات/phonology)? & 25 & \\
Have you ever learned about makhroz in formal school? & 21 & 4 \\
Have you ever learned about makhroz besides in formal school? & 25 & 0 \\
$\begin{array}{l}\text { Have you been able to correctly pronounce every letter when } \\
\text { reciting Al-Qur'an }\end{array}$ & 25 & 0 \\
\hline
\end{tabular}

Based on the data presented in the table above, it has been identified that the majority of students stated that they had learned about the phonology of AlQur'an. There were 21 (84\%) students who stated that they had studied the phonology of Al-Qur'an in formal schools and $25(100 \%)$ students had studied 
outside formal schools. Through the interviews, the students were asked "Besides in a formal school, where did you study the phonology of Al-Qur'an?" From the answers, 10 (40\%) students had learned in boarding schools, 13 (52\%) students had learned from the Al-Qur'an education institution, and 2 (8\%) students had learned from their parents. Based on the table, all students stated that they had been able to correctly pronounce the sounds of each letter when they recite Al-Qur'an. however, this was only statements and they needed to be validated.

Next, this study explored students' perceptions and motivations in learning the phonology of Al-Qur'an by asking a number of questions using the Likert scale. The results are presented in Table 3 as follows.

Table 3. Motivation for Learning Al-Qur'an Phonology

\begin{tabular}{lccccc}
\hline $\begin{array}{l}\text { Motivation for Learning Al- } \\
\text { Qur'an Phonology }\end{array}$ & $\begin{array}{l}\text { Strongly } \\
\text { Disagree }\end{array}$ & Disagree & $\begin{array}{l}\text { Rather } \\
\text { Disagree }\end{array}$ & Agree & $\begin{array}{l}\text { Strongly } \\
\text { Agree }\end{array}$ \\
\hline $\begin{array}{l}\text { In reciting Al-Qur'an, it is } \\
\text { important to pay attention to } \\
\text { correct pronunciation of } \\
\text { hijaiyyah letters }\end{array}$ & 0 & 0 & 0 & 3 & 22 \\
$\begin{array}{l}\text { Every Muslims must master } \\
\text { makhorijul letters }\end{array}$ & 1 & 1 & 20 & 3 \\
$\begin{array}{l}\text { Besides Arab people, no one else } \\
\text { is able to pronounce hijaiyyah } \\
\text { letters in Al-Qur'an correctly. }\end{array}$ & 1 & 2 & 0 & 22 & 0 \\
\hline
\end{tabular}

Based on the data presented in Table 3, it has been identified that the students had strong opinion about the importance of learning and mastering Al-Qur'an phonology. However, a statement was suspected, namely 22 students agreed that besides Arab people, no one would not be able to pronounce the sounds of the hijaiyyah letters correctly. This means that they did not believe in their accuracy of the sound of the hijaiyyah when reciting Al-Qur'an because they assumed that only Arabs can pronounce the sounds of the letters of Al-Qur'an correctly. Such a view greatly narrows the teachings of Islam as if Al-Qur'an is only reserved for Arabs, even though Islam is actually a religion that is intended for all humans. This means that when all Muslims are required to read AlQur'an as a source of Islamic teachings, Al-Qur'an can be spoken fluently by everyone without exception as long as it is studied as well as possible. There are many Indonesian qori (Al-Quran readers) who excel at the international level. For example, Mu'min Ainul Mubarok from Tasikmalaya, West Java, was the champion of the 50th MTQ (MusabaqohTilawatil Qur'an, Al-Quran Reciting Competition) International level 1 in Malaysia in 2008.Another example is Darwin Hasibuan from Rantau Prapat, North Sumatra, was the $2^{\text {nd }}$ winner of MTQ International level in New Delhi, India in 2003. These examples have 
actually contradicted the opinion that only Arabs are fluent in reading $\mathrm{Al}$ Qur'an.

In light of this suspicion, Al-Qur'an reciting tests were conducted for the students who were the subject of the research. The tests were given to the students using a test instrument which was reciting surah al-Fatihah. The reason for choosing al-Fatihah was because it is short and familiar to students. Additionally, for a Muslim, recitation of al-Fatihah is part of the pillar of prayer (Al Jaziri, 1994; Wakaf, Kementrian \& Kuwait, 1986). The correct recitation of alFatihah for every Muslim is compulsory in accordance with the tajwid.If it is misread, then the prayer becomes invalid. According to the hadith of the prophet Muhammad SAW, that there is no prayer for those who do not read alFatihah (Bukhori, 1992 No 714). According to Taufiqurrochman (2007), in reading al-Fatihah, it is important to note that there are 144 letters, and when the number of tasydid is included, then the number of letters in al-Fatihah is 154 letters because the tasydid sign refers to 2 letters. If these letters are not read out of error or because of the reduction of tasydid, then their prayers are invalid because the recitation of al-Fatihah is incomplete.

The test results showed a number of errors the students made in reciting the letters in a number of verses in surah al-Fatihah. A total of $24(96 \%)$ students made a mistake in reading al-Fatihah letters belonging to LahnJali (major) and 1 (4\%) students belonged to the LahnKhafi (minor) class. This fact was inversely proportional to the student's acknowledgment that they have been able to pronounce the hijaiyyah letters correctly. In addition, the findings indicated a very worrisome situation as the mispronunciation belonged to LahnJali where such a form of confusion is banned since it can change the meaning of AlQur'an.

From these findings, imla or transliteration tests from Arabic to Latin were conducted.The tests were done to analyze the mastery of the students' makhroz (Al-Qur'an phonology) theory. In this test, the students were instructed to transliterate surah al-Fatihah from Arabic into Latin. The transliteration guidelines referred to the Joint Decision Letter of the Minister of Religion and the Minister of Education and Culture of the Republic of Indonesia Number 158 of 1987 and Number 0543b/U/1987 on the guidelines of Arabic Latin transliteration. The results of the transliteration test on surah al-Fatihah are presented in Table 4.

Table 4. Results of the Al-Fatihah Transliteration Test

\begin{tabular}{lll}
\hline Al-Fatihah Transliteration & Correct & Incorrect \\
\hline Verse 1 & 24 & 1 \\
Verse 2 & 25 & 0 \\
Verse 3 & 24 & 1 \\
Verse 4 & 25 & 0 \\
Verse 5 & 23 & 2 \\
Verse 6 & 24 & 1 \\
Verse 7 & 22 & 3 \\
\hline
\end{tabular}


The test results showed that in theory, most students had understood the sound of the hijaiyyah letters found in surah al-Fatihah. However, in practice, there were difficulties in producing the sounds, resulting in numerous phonological interference in pronouncing the hijaiyyah letters. Based on these findings, it is concluded that a series of actions are needed in an attempt to minimize phonological interference in reciting Al-Quran especially in reciting al-Fatihah by Javanese speaker students.

\subsection{Critical Action and Evaluation of the Al-Qur'an Phonological Interference}

From the results of the aforementioned pre-action analysis, this study produced five stages of learning the phonology of Al-Qur'an. These five stages also involved reflective and critical steps in each implementation. The following are the five stages in which each stage is accompanied by detailed observation to observe students' responses.

\section{Stage 1: Listening to and Documenting the Recitation}

This stage was the stage for collecting data on forms of errors in reciting surah al-Fatihah made by students. The way to do this was to listen to the students reciting one by one and then provide notes on student's recitation.

In order for the researchers to focus on listening to the students'recitation, tutors were involved as a collaborative team from the student element to document each student's recitation in the form of audio recordings. The recording was done to facilitate analysis and minimize human error in listening to al-Fatihah recitation by the students. Using the record, verification on the test notes and the evidence of the recording was easy, so that the data on the pronunciation of each letter was maintained. An example of a recording of a student's practice of reciting al-Fatihah is depicted in Figure 3 as follows.

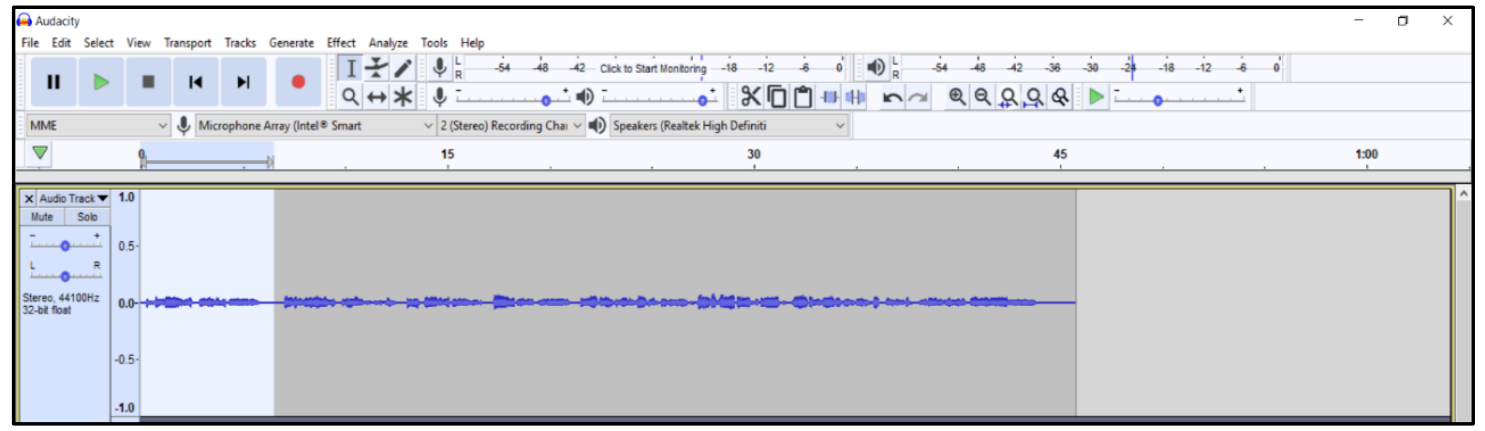

Figure 3: Results of Recording of Surah Al-Fatihah from One of the Students

By using the Audacity application, the entire recitation of every verse could be repeated or reviewed. For example, Verse 1 is displayed in the following figure. 


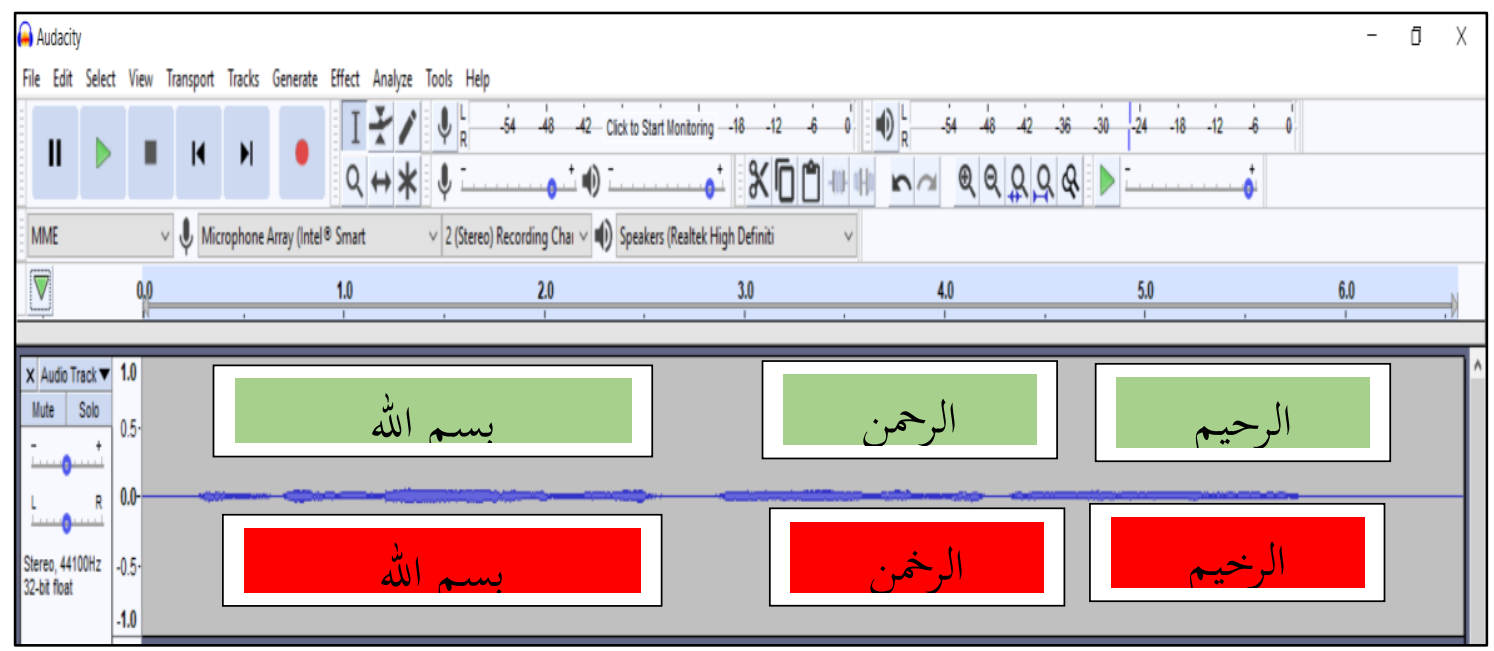

Figure 2. Record Data Display of Verse 1 of Surah Al-Fatihah

The green sign is the correct pronunciation and the red sign is the student's pronunciation so that phonological interference can be seen when it occurs. Likewise, the following verses such as Verse 2 is shown in the following figure.

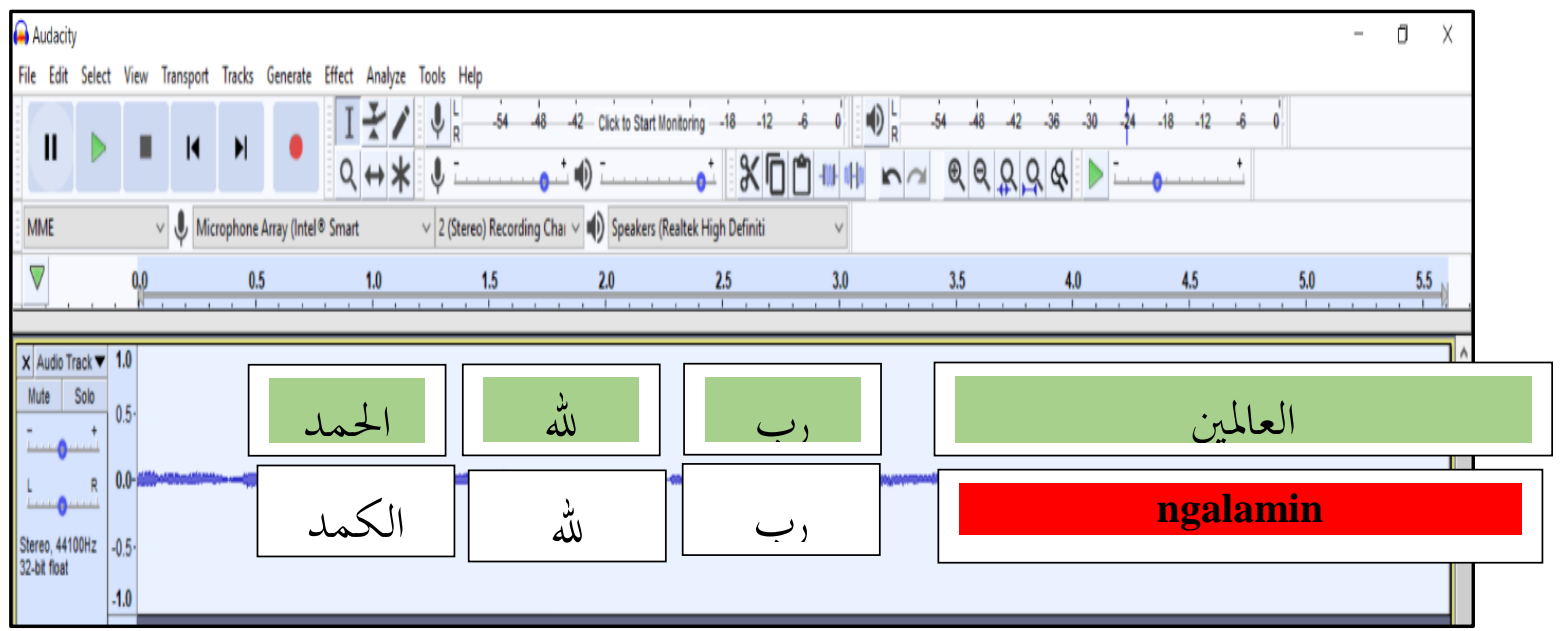

Figure 3. Record Data Display of Verse 2 of Surah Al-Fatihah

From this Stage 1, a number of findings were found in the existence of pronunciation deviations in the practice of reciting surah al-Fatihah. The deviations are presented in Table 5 as follows.

Table 5. Hijaiyyah Letter Sound Deviation in the Recitation Al-Fatihah

\begin{tabular}{|c|c|c|c|c|}
\hline No & Sound & Correct Lafazh & Deviation & Change \\
\hline 1 & $\begin{array}{c}\tau \\
{[\mathrm{h}]}\end{array}$ & 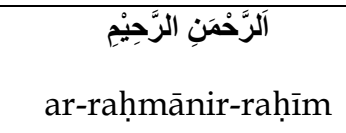 & 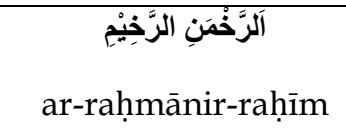 & حinto $\dot{\tau}$ [kh] \\
\hline 2 & $\begin{array}{c}\tau \\
{[\mathrm{h}]}\end{array}$ & 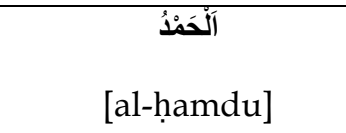 & \begin{tabular}{c}
\multicolumn{1}{c}{${ }^{c}$} \\
[al-ḥamdu]
\end{tabular} & حinto s [k] \\
\hline
\end{tabular}




\begin{tabular}{|c|c|c|c|c|}
\hline 3 & $\begin{array}{c}\varepsilon \\
{\left[{ }^{\prime}\right]}\end{array}$ & $\begin{array}{c}\text { العَالَمبِيْنَ } \\
\text { '[ālamīn] }\end{array}$ & Ngalamiin & ‘ainto nga \\
\hline 4 & [d] & $\begin{array}{c}\text { الألَّيْنِ } \\
\text { [ad-dīni] }\end{array}$ & 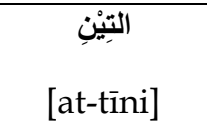 & $د$ into ت \\
\hline 5 & $\begin{array}{l}\varepsilon \\
{\left[{ }^{\prime}\right]}\end{array}$ & 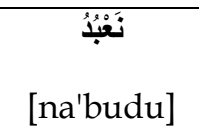 & 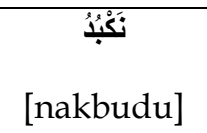 & عinto ك [k] \\
\hline 6 & $\begin{array}{l}\text { ص } \\
\text { [s] }\end{array}$ & $\begin{array}{c}\text { صبرَاطِ } \\
\text { [șirāța] }\end{array}$ & 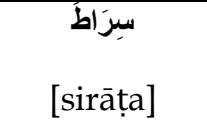 & [s] س ص \\
\hline 7 & $\begin{array}{c}\dot{j} \\
{[\dot{z}]}\end{array}$ & $\begin{array}{c}\text { أَلَذْينَ } \\
\text { [Allażīna] }\end{array}$ & $\begin{array}{c}\text { أَلْيَيْنَ } \\
\text { [Alladīna] }\end{array}$ & $ذ$ \\
\hline 8 & $\begin{array}{c}\text { G] } \\
\text { [q] }\end{array}$ & 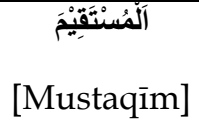 & $\begin{array}{c}\text { [ألمُسْنَكِكيمْ } \\
\text { [Mustakīm] }\end{array}$ & 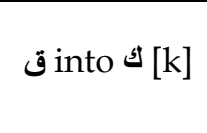 \\
\hline 9 & $\begin{array}{c}\varepsilon \\
{\left[{ }^{\prime}\right]}\end{array}$ & $\begin{array}{c}\text { أَنْعَنْتَ } \\
\text { [an'amta] }\end{array}$ & $\begin{array}{c}\text { أَنَأَنَت } \\
\text { [anamta] }\end{array}$ & Einto I [a] \\
\hline
\end{tabular}

In addition to the findings above, other forms of sound deviation were found. For example, in the lafazh يَوْر (yaumi) in the sentence يوم الدين there was a tendency to change the sound of vowel $u$ to $o$, namely "yaomiddin" and lafazh (gairi) in the sentence غير المغضوب tended to change from $i$ to $e$ namely "goeri'. Furthermore, there were also forms of tasydid reduction in lafazh إِيَالك to these findings reinforced the results of research carried out by several previous researchers namely Taufiqurrochman (2007) when examining phonological interference in the Cilacap community, namely the change in the letter $\varepsilon$ into

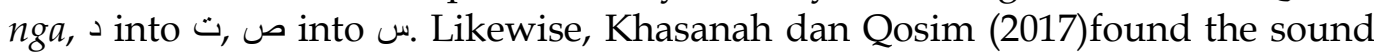
change in Verse 2 of surah al-Fatihah of the letter $\varepsilon$ becomes $n g a$ because the letter $\varepsilon$ is in the beginning of the word. The Javanese people do not know the consonant $\varepsilon$ which is only the letter ngo contained in Javanese language letters. In Verse 5, the letter $\varepsilon$ becomes 5 because it is in the middle of the word.

\section{Stage 2: Observation and Grouping of Phonological Interference Problems}

Based on the findings in Stage 1, the records were observed to map out the form of phonological interference made by the students. This mapping referred to the instrument as shown in Table 1. This mapping was done as an initial step in designing an action so that it was on target and reached the target as expected in realizing a desired change. Referring to the indicators as in Table 1, the results of the recitation test of surah al-Fatihah are presented in the following table. 
Table 6. Test Results for Surah Al-Fatihah

\begin{tabular}{|c|c|c|c|c|c|c|c|c|c|c|c|c|c|c|}
\hline \multirow{2}{*}{$\begin{array}{l}< \\
0 \\
\substack{0 \\
0 \\
0}\end{array}$} & \multirow[t]{2}{*}{ Word } & \multirow{2}{*}{$\begin{array}{l}\text { Meanin } \\
\mathrm{g}\end{array}$} & \multicolumn{7}{|c|}{ Major } & \multicolumn{5}{|c|}{ Minor } \\
\hline & & & $\begin{array}{l}\text { LJ } \\
1\end{array}$ & $\begin{array}{l}\text { LJ } \\
2\end{array}$ & $\begin{array}{l}\text { LJ } \\
3\end{array}$ & $\begin{array}{l}\text { LJ } \\
4\end{array}$ & $\begin{array}{l}\text { LJ } \\
5\end{array}$ & $\begin{array}{l}\text { LJ } \\
6\end{array}$ & LJ7 & Lk1 & $\begin{array}{l}\text { LK } \\
2 \\
\end{array}$ & $\begin{array}{l}\text { LK } \\
3 \\
\end{array}$ & LK4 & $\begin{array}{l}\text { LK } \\
5\end{array}$ \\
\hline \multirow{4}{*}{1} & $\begin{array}{c}\text { بسismi] } \\
\text { [Bisin }\end{array}$ & $\begin{array}{l}\text { In the } \\
\text { name of }\end{array}$ & 0 & 0 & 0 & 0 & 0 & 0 & 0 & 0 & 0 & 0 & 0 & 0 \\
\hline & $\begin{array}{c}\text { اللّh] } \\
\text { [allāhi] }\end{array}$ & Allah & 0 & 0 & 0 & 0 & 0 & 0 & 0 & 0 & 0 & 0 & 0 & 0 \\
\hline & $\begin{array}{c}\text { [arraḥmā } \\
\text { ni] }\end{array}$ & $\begin{array}{l}\text { the Most } \\
\text { Graciou } \\
\text { s }\end{array}$ & 22 & 0 & 0 & 0 & 0 & 0 & 0 & 0 & 0 & 0 & 0 & 0 \\
\hline & $\begin{array}{c}\text { الرحيh] } \\
\text { [arrahim] }\end{array}$ & $\begin{array}{l}\text { The } \\
\text { Most } \\
\text { Merciful }\end{array}$ & 23 & 0 & 0 & 0 & 0 & 0 & 0 & 0 & 0 & 0 & 0 & 0 \\
\hline \multirow{4}{*}{2} & $\begin{array}{c}\text { الحمد } \\
\text { [al- } \\
\text { hamdu] }\end{array}$ & $\begin{array}{l}\text { All } \\
\text { praises } \\
\text { and } \\
\text { thanks }\end{array}$ & 18 & 0 & 0 & 0 & 0 & 0 & 0 & 0 & 0 & 0 & 0 & 0 \\
\hline & 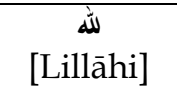 & $\begin{array}{l}\text { [be] to } \\
\text { Allah }\end{array}$ & 0 & 0 & 0 & 0 & 0 & 0 & 0 & 0 & 0 & 0 & 0 & 0 \\
\hline & 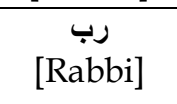 & $\begin{array}{l}\text { [the } \\
\text { Lord] }\end{array}$ & 0 & 0 & 0 & 0 & 0 & 0 & 0 & 0 & 0 & 0 & 0 & 0 \\
\hline & $\begin{array}{c}\text { العالمين } \\
\text { [al- } \\
\text { 'ālaminn] }\end{array}$ & $\begin{array}{l}\text { of all the } \\
\text { worlds }\end{array}$ & 19 & 0 & 0 & 0 & 0 & 0 & 0 & 0 & 0 & 0 & 0 & 0 \\
\hline \multirow[t]{2}{*}{3} & $\begin{array}{c}\text { ألرحمن } \\
\text { [arrahmmā } \\
\text { ni] }\end{array}$ & $\begin{array}{l}\text { The } \\
\text { Most } \\
\text { Graciou } \\
\text { s }\end{array}$ & 22 & 0 & 0 & 0 & 0 & 0 & 0 & 0 & 0 & 0 & 0 & 0 \\
\hline & $\begin{array}{c}\text { الرحي̄m] } \\
\text { [arrahim] }\end{array}$ & $\begin{array}{l}\text { The } \\
\text { Most } \\
\text { Merciful }\end{array}$ & 23 & 0 & 0 & 0 & 0 & 0 & 0 & 0 & 0 & 0 & 0 & 0 \\
\hline \multirow{3}{*}{4} & 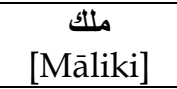 & Master & 0 & 0 & 0 & 0 & 0 & 0 & 0 & 0 & 0 & 0 & 0 & 0 \\
\hline & $\begin{array}{c}\text { [Yaumi] } \\
\text { [Yaumi] }\end{array}$ & $\begin{array}{l}\text { [of the] } \\
\text { Day }\end{array}$ & 0 & 0 & 0 & 0 & 0 & 0 & 0 & 8 & 0 & 0 & 0 & 0 \\
\hline & $\begin{array}{c}\text { الدين] } \\
\text { [ad-dinn] }\end{array}$ & $\begin{array}{l}\text { [Of the] } \\
\text { Judgem } \\
\text { ent }\end{array}$ & 13 & 0 & 0 & 0 & 0 & 0 & 0 & 0 & 0 & 0 & 0 & 0 \\
\hline \multirow{4}{*}{5} & $\begin{array}{c}\text { اليَّأكَ } \\
\text { [Iyyāka] }\end{array}$ & $\begin{array}{l}\text { You } \\
\text { Alone }\end{array}$ & 0 & 0 & 0 & 0 & 9 & 0 & 0 & 0 & 0 & 0 & 0 & 0 \\
\hline & 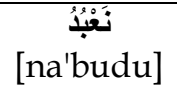 & $\begin{array}{l}\text { we } \\
\text { worship }\end{array}$ & 8 & 0 & 0 & 0 & 0 & 0 & 0 & 0 & 0 & 0 & 0 & 0 \\
\hline & $\begin{array}{c}\text { وَايَّاَكَّكَ } \\
\text { [wa } \\
\text { iyyāka] }\end{array}$ & $\begin{array}{l}\text { and You } \\
\text { Alone }\end{array}$ & 0 & 0 & 0 & 0 & 9 & 0 & 0 & 0 & 0 & 0 & 0 & 0 \\
\hline & $\begin{array}{c}\text { [nasta'īn] } \\
\text { [nتعين }\end{array}$ & $\begin{array}{l}\text { we ask } \\
\text { for help }\end{array}$ & 0 & 0 & 0 & 0 & 0 & 0 & 0 & 0 & 0 & 0 & 0 & 0 \\
\hline 6 & $\begin{array}{c}\text { اهدdina] } \\
\text { [Ihd }\end{array}$ & $\begin{array}{l}\text { Guide } \\
\text { us }\end{array}$ & 0 & 0 & 0 & 0 & 0 & 0 & 0 & 0 & 0 & 0 & 0 & 0 \\
\hline
\end{tabular}




\begin{tabular}{|c|c|c|c|c|c|c|c|c|c|c|c|c|c|c|}
\hline & $\begin{array}{c}\text { الصراط } \\
\text { aș-șirāṭa }\end{array}$ & $\begin{array}{l}\text { to the } \\
\text { path }\end{array}$ & 17 & 0 & 0 & 0 & 0 & 0 & 0 & 0 & 0 & 0 & 0 & 0 \\
\hline & $\begin{array}{l}\text { المستقيم } \\
\text { [al- } \\
\text { mustaqī } \\
\text { m] }\end{array}$ & $\begin{array}{l}\text { That is } \\
\text { straight }\end{array}$ & 19 & 0 & 0 & 0 & 0 & 0 & 0 & 0 & 0 & 0 & 0 & 0 \\
\hline & $\begin{array}{c}\text { صراطāta] } \\
\text { [șing }\end{array}$ & $\begin{array}{l}\text { The } \\
\text { path }\end{array}$ & 17 & 0 & 0 & 0 & 0 & 0 & 0 & 0 & 0 & 0 & 0 & 0 \\
\hline & $\begin{array}{c}\text { [șirāṭa] } \\
\text { [الذين }\end{array}$ & $\begin{array}{l}\text { [Of] } \\
\text { those }\end{array}$ & 16 & 0 & 0 & 0 & 0 & 0 & 0 & 0 & 0 & 0 & 0 & 0 \\
\hline & $\begin{array}{c}\text { انعمت } \\
\text { [an'amta] }\end{array}$ & $\begin{array}{l}\text { You } \\
\text { have } \\
\text { bestowe } \\
\mathrm{d} \text { [your] } \\
\text { favors }\end{array}$ & 16 & 0 & 0 & 0 & 0 & 0 & 0 & 0 & 0 & 0 & 0 & 0 \\
\hline & ['alaihim] & of them & 20 & 0 & 0 & 0 & 0 & 0 & 0 & 0 & 0 & 0 & 0 & 0 \\
\hline 7 & $\begin{array}{l}\text { غير } \\
\text { gairi }\end{array}$ & Not [of] & 0 & 0 & 0 & 0 & 0 & 0 & 0 & 13 & 0 & 0 & 0 & 0 \\
\hline 1 & 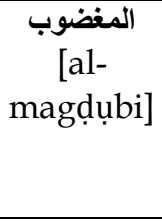 & $\begin{array}{l}\text { Those } \\
\text { who } \\
\text { earned } \\
\text { [Your] } \\
\text { wrath }\end{array}$ & 17 & 0 & 0 & 0 & 0 & 0 & 0 & 0 & 0 & 0 & 0 & 0 \\
\hline & ['alaihim] & $\begin{array}{l}\text { on } \\
\text { themsel } \\
\text { ves }\end{array}$ & 0 & 0 & 0 & 0 & 0 & 0 & 0 & 0 & 0 & 0 & 0 & 0 \\
\hline & $\begin{array}{l}\text { ولالضالئ } \\
\text { wa laḍ- } \\
\text { dâllīn }\end{array}$ & $\begin{array}{l}\text { And not } \\
\text { [of] } \\
\text { those } \\
\text { who go } \\
\text { astray }\end{array}$ & 0 & 0 & 0 & 0 & 0 & 0 & 0 & 0 & 0 & 0 & 0 & 0 \\
\hline
\end{tabular}

The Arabic transliteration is according to: Surat Keputusan Bersama Menteri Agama dan Menteri Pendidikan dan Kebudayaan Republik No. 158 year 1987 and number : 0543b/U/1987.

Based on the data presented in Table 6, it has been identified that there are three forms of errors in the recitation of al-Fatihah, namely: 1) changes in letters (LJ1), 2)tasydid deduction (LJ 5), and 3) imperfections in the pronunciation of the harakat (LK1). Points 1 and 2 are categorized as lahn jali or major error. As for point 3,it was categorized as khafi or minor error. Of the three forms of errors, the most frequent error made by the students was LJ1 which is the change of the sound of a letter with another letter. The errors were identified in the letters $\tau-\varepsilon$

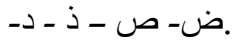

To verify these findings, the students' perceptions about the sound of hijaiyyah letters that they find difficult were explored. Verification was done by surveying the students by asking "between the following hijaiyyah letters: which letters are the most difficult to pronounce?" The survey results are presented as follows. 


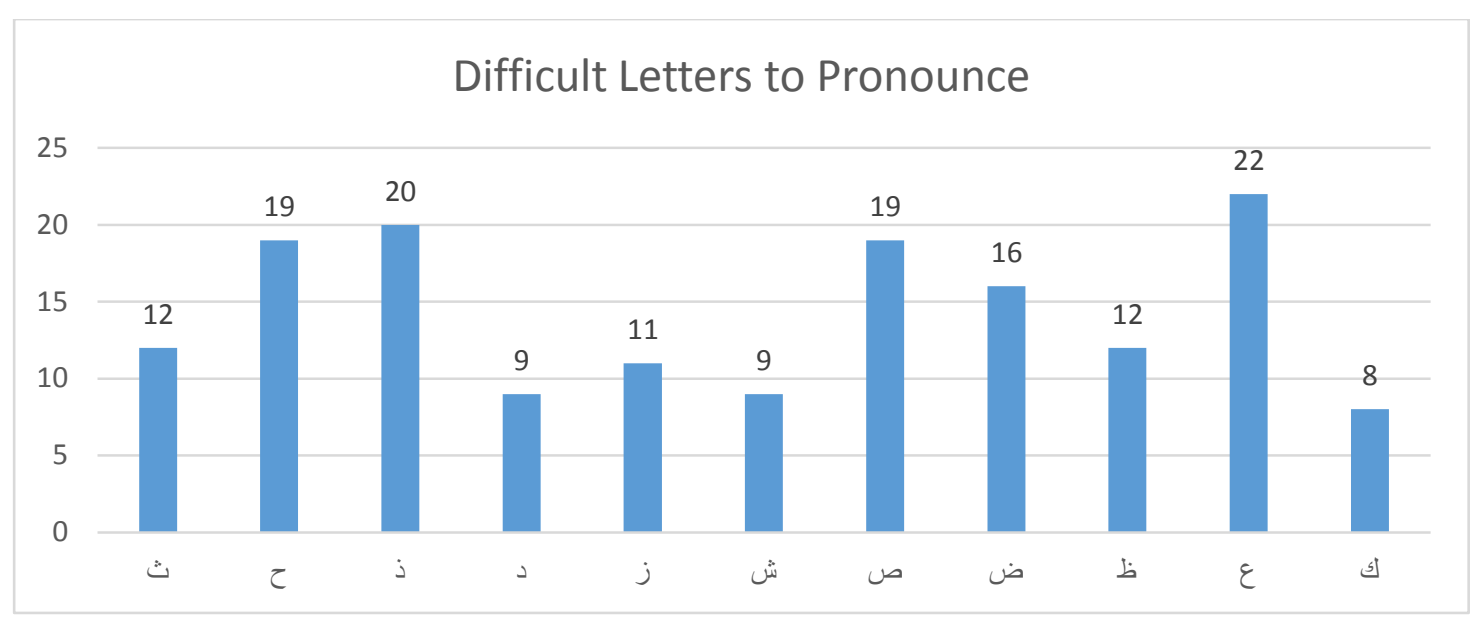

Figure 4. Hijaiyyah Sounds that Were Difficult to Recite by the Students

Based on the results of the survey, there was a match with the findings regarding the mistakes of students in reciting letters in the practice of reciting surah al-Fatihah. The findings identified interference in the sound of the letters $\tau$ ض -ص - ذ - د - ع- From the six letters, the most difficult letter to recite in reciting Al-Qur'an was $ح$ stated by $19(76 \%)$ students, the letter $\varepsilon$ stated by $22(92 \%)$ students, the letter $\dot{\mathrm{s}}$ stated by $20(80 \%)$ students, the letter $د$ stated by $9(36 \%)$ students, the letter ص stated by 19 (76\%) students, and the letter ض stated by 16 (64\%) students.

These findings also further strengthened what was expressed by Khasanah and Qosim (2017) that the main factor causing interference that leads to errors in reciting Al-Qur'an for non-Arab (Indonesian) people are the contrast of phonetic systems between the local language and Arabic language. The Arabic language consists of 28 consonants and the Indonesian language consists of only 24 consonants that are not so different from the Javanese language. This means that there are several sounds of Arabic that are not found in Indonesian for example $\dot{ }$ - - - - - - ح - ع - ص which tend to cause errors in the pronunciation. Therefore, phonological interference is also very closely related to sociolinguistic and phonological studies. Sociolinguistics as a study of language associated with community conditions and phonology is a branch of the underlying field in linguistics, namely the language sounds (Al-Khuli, 1982; Crystal, 1992). Interference can occur in all components of language, namely the sound, sentence order, word order, and meaning (Aslinda, 2007).

Based on these findings, it can also be understood that theoretically the students from Java understood the concepts and theories of reciting hijaiyyah letters and this was proven in the written test with Arabic to Latin transliteration in which the majority has mastered the transliteration. However, in pronunciation practice, there were many mistakes and they had an impact on the change in meaning. For example, in the reduction of tasydid in Verse 5, namely نعبدوَاليَّاكَكَ إِكَّكَكَ ن ذ سد تع ين which means "only to You we worship and only to You we beg for help." If the tasydid is not read, it basically removes one letter and its meaning into "sunlight"(Al-Malibari, 2004 p.140). 


\section{Stage 3. Development of Teaching Materials}

Based on the findings in Stage 2, teaching materials that can be used to minimize phonological interference in the recitation of Al-Qur'an were explored and developed. The search found teaching resources and materials that can be used in phonology learning based on information and communication technology (ICT) namely the Learn Quran Tajwid (LQT), an Android-based mobile phone application developed by www.learn-quran.co that has 22 learning topics and can be downloaded from Play Store.

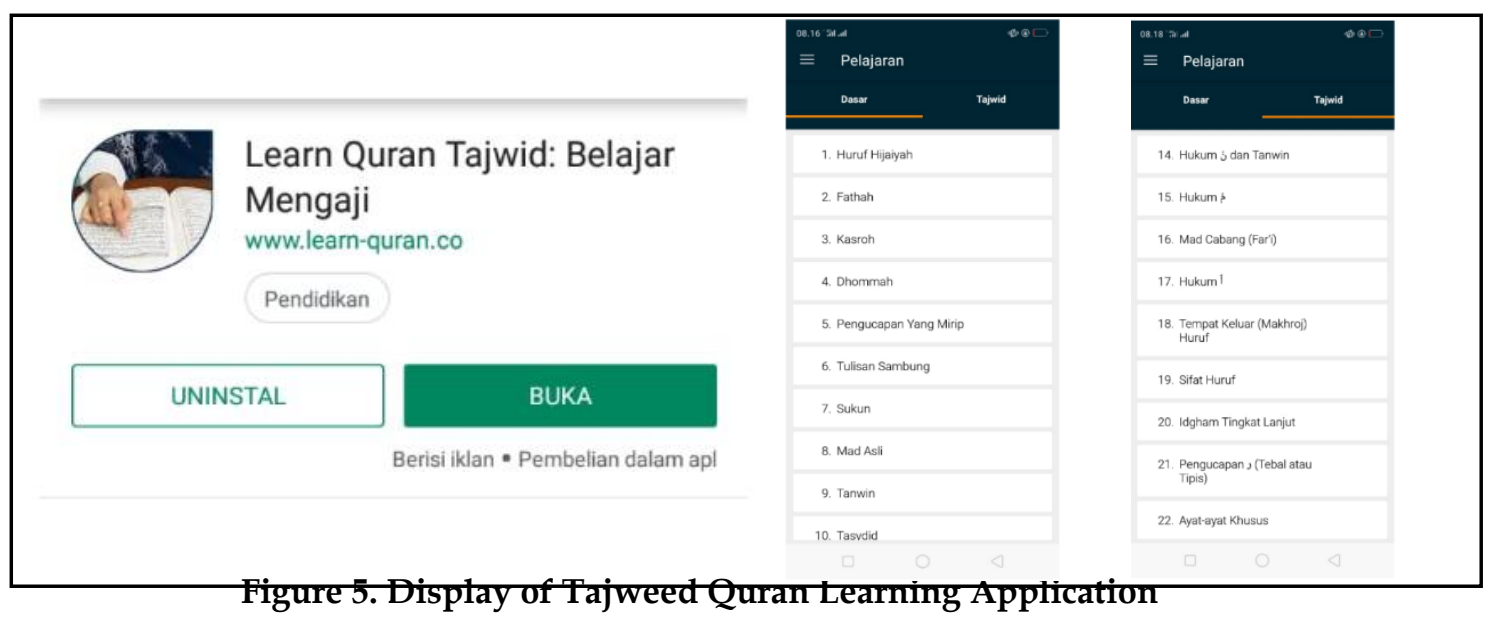

Of the 22 topics, there are four topics that can be used in learning the phonology of Al-Qur'an, including the topic of hijaiyyah, the pronunciation of letters with similar sounds, and the letters and characteristics. Each topic is equipped with a theory, namely a basic explanation of knowledge and examples, accompanied by sound pronunciation, images, and videos. In addition, each topic is equipped with exercises that can improve skills, and tests that measure the mastery of the topic.
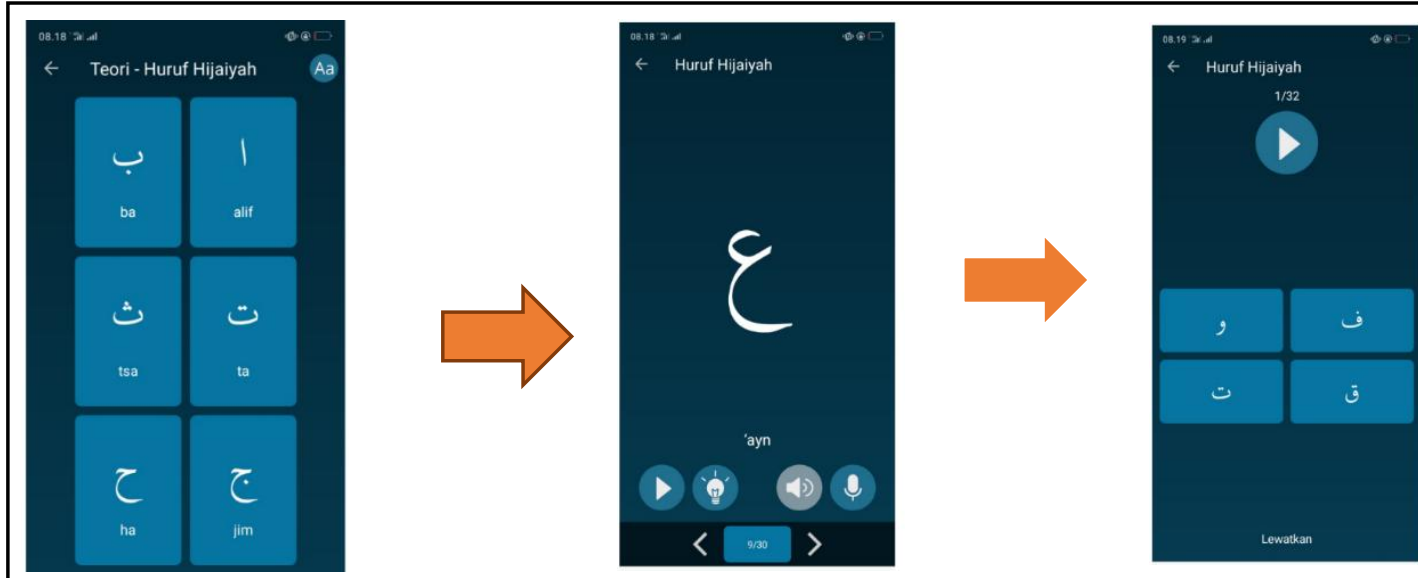

Figure 6. Display of the Theories, Exercise, and Tests in the LQT application 
Apart from topics that are quite representative in the Al-Qur'an learning, the application is equipped with several features including: 1) sound features that contain examples of how to pronounce each hijaiyyah letter so that it can be learned correctly; 2) images in explaining makhroz and the pronunciation of ishmam that required video; 3 ) subtitles and highlights that are equipped with transliteration of Indonesian writing from Arabic text and highlight topics that can be displayed or omitted to help study 4) recording feature to record the learner's voice that can be compared to the correct voice and can be checked by the teacher at a later time; and 5) examples used in theory, exercises, and tests that are taken from the Al-Quran to make it familiar with the Arabic vocabulary.

The use of ICT-based applications as learning media is a form of adaptation with the style of learning and teaching in the $21^{\text {st }}$ century. As stated by Saavedra and Opfer (2012) about nine principles of teaching skills in the 21st century, one of them is utilizing technology to support learning. In addition, using this media, every individual must be involved in inquiry-based learning that is meaningful, has truth value, and relevance, to develop the needed high-level thinking skills (Barron \& Darling-Hammond, 2008).

\section{Stage 4. The Process of Phonology Learning}

After Stage 3, the learning process of Al-Qur'an phonology commenced by referring to the source and learning media as in Stage 3. The learning process was carried out in the following steps.

In the first step, the students were instructed to download the LQT application available from Play Store on their smart phones. Next, the features available in the application were explained until the students understood them well.

In the second step, the students were instructed to learn and master the sounds of the hijaiyyah letters on four topics in the LQT application namely the topic of hijaiyyah, the topic of pronunciation of letters with similar sounds, the topic of makhroz and characteristics of letters and focused only on learning letters that were difficult to pronounce or letters that are incorrectly pronounced when

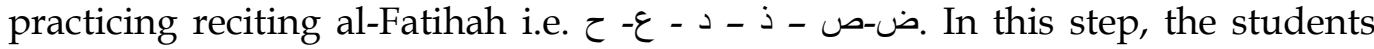
learned the theory of letters, for example the sound of the letter and then practiced it.

Using the training feature, the students tried to record the sound of the letter and then compared it with the example in the application. After completing the second step, in the third step, the students were instructed to use the test feature to measure the extent of their mastery of the sound.

The efforts to correct other forms of error such as the reduction of tasydid on

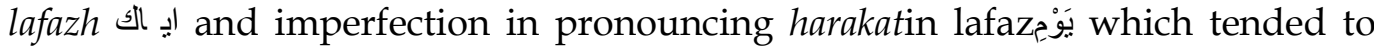
read "yaomi" and lafazh غَيِْ which tended to read "goeri", additional to being exemplified classically in class, the students were also instructed to listen to murotal (recitation) of surah al-Fatihah from the most popular qori, for example Sheikh As-Sudais.

This learning process took 3 weeks. The first week was spent with installing the application, explaining the features, and learning the theory of letters which 
became a problem in the practice of reciting Al-Qur'an. The second week was used for discussing the character of letters, makhroz of letters and letter with similar sounds. The third week was used to evaluate learning outcomes.

\section{Stage 5. Final Test of Learning}

This stage evaluated the learning outcomes of the phonology of Al-Qur'an. The aspects evaluated in the learning process are as follows:

\section{Regarding the learning resources}

To evaluate the learning resources and learning media, a number of surveys on the Guttman scale was conducted. The survey results can be described as follows.

Table 7. Results of Learning Media Evaluation

\begin{tabular}{lll}
\hline Usage of LQT Application & Yes & No \\
\hline Is the LQT application user friendly? & 25 & 0 \\
$\begin{array}{l}\text { Does the LQT application help you in learning phonology? } \\
\text { Do the materials in the LQT application representative enough for }\end{array}$ & 23 & 2 \\
$\begin{array}{l}\text { the learning of Al-Qur'an phonology? } \\
\text { Do your skills improve by using the LQT application? }\end{array}$ & 25 & 0 \\
\hline
\end{tabular}

The table provides information that $25(100 \%)$ students stated that the LQT application was user friendly, $23(92 \%)$ stated that the LQT application helped them to learn the phonology of the letters of Al-Qur'an, and 23 (92\%) students stated that the materials in the LQT application were quite representative in studying the phonology of Al-Qur'an. All students stated that by using the LQT application, they felt that their skills had improved. Thus, the LQT application was a source and learning media that could be accepted by the students. From the results of interviews with several students, it could be concluded that the LQT application was practical and user friendly so that learning about theology of the Qur'an is not only limited to classrooms but can be done anywhere and at any time.

\section{Assessment of Perception of Hijaiyyah Letter Pronunciation}

After evaluating the use of learning media with the LQT application, the

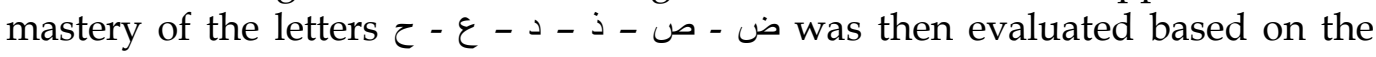
students' own perceptions of the assessment. The results of the perceptional review of the mastery of the hijaiyyah letters are as follows. 
Table 8. Perceptional Evaluation Results

\begin{tabular}{|c|c|c|}
\hline Mastery of letter pronunciation & Yes & No \\
\hline I am able to pronounce the letters ض - ض- ح- ح correctly & 25 & 0 \\
\hline My recitation of surah al-Fatihah is correct based on tajwid standard & 25 & 0 \\
\hline
\end{tabular}

From the table above it can be concluded that all students stated that they were able to pronounce the letters $ح$ - ض - ص - ذ - د - properly and correctly and were able to recite surah Al-Fatihah in accordance with the standard of recitation.

\section{Phonological Learning Objective Assessment}

In order to verify the perceptional assessment, a number of tests was performed as a form of evaluation. The first test was to recite the letters by reciting the letters in one syllable arrangement as the results of previous research:

Example1. Hijaiyyah letter Alif

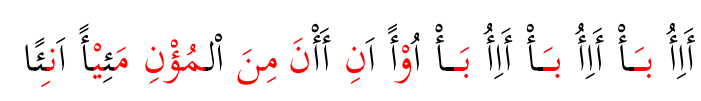

Example 2. Hijaiyyah letter $B a$

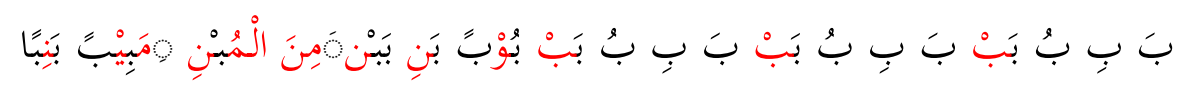

Example 3. Hijaiyyah letter $\mathrm{Ta}$

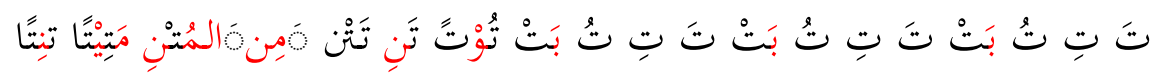

The recitation above followed the melody as follows.

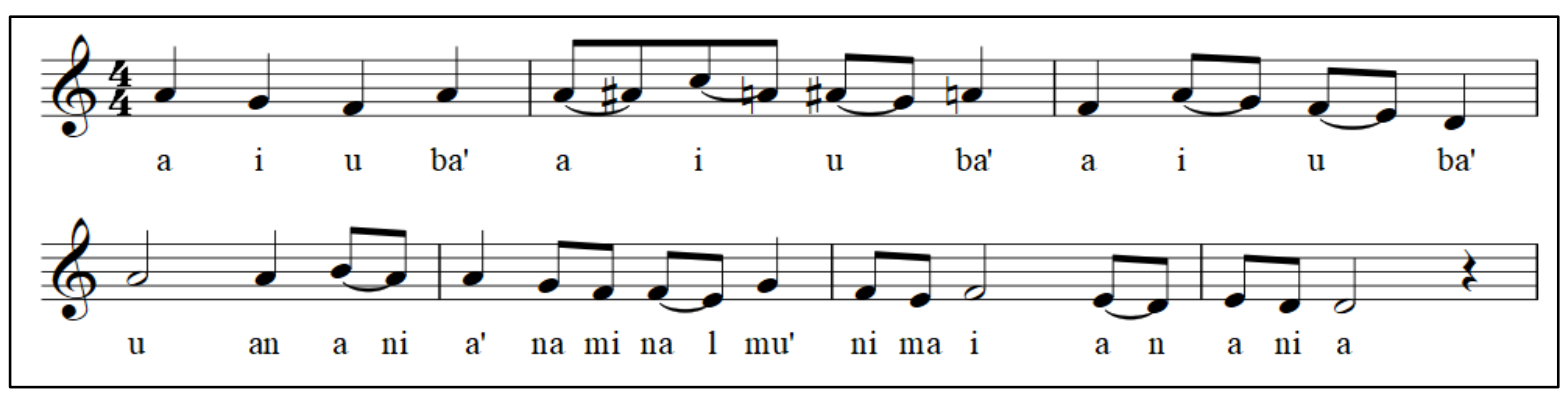

Figure 7. Melody of the Makhroj Exercise (Supriyadi \& Julia, 2019)

The results of the evaluation of the pronunciation of the sounds of the hijaiyyah letters are as follows. 
Table 9. Results of Objective Evaluation of Phonology Learning

\begin{tabular}{lll}
\hline Mastery of Sound & Correct & Incorrect \\
\hline$\tau$ & 25 & 0 \\
$\varepsilon$ & 24 & 1 \\
$د$ & 25 & 0 \\
$\dot{L}$ & 24 & 1 \\
$ص$ & 23 & 2 \\
$ض$ & 25 & 0 \\
\hline
\end{tabular}

The table informs that after the learning, the problematic letters in the practice of reciting surah al-Fatihah by students could be pronounced and mastered well, except the letters $\varepsilon$ and $د$ in which only $96 \%$ or 24 students mastered the pronunciation of the sound. As for the letter $ص$, only $92 \%$ or 23 students mastered it.

Furthermore, a number of semi-structured interviews were conducted with students who still made mistakes or had not mastered the pronunciation of the letters $\varepsilon$ and $ص$ by asking a number of questions. To the question "do you often practice to master the sound of the letter outside the class?:, the answer was "rarely". To the question "do you know that the pronunciation of letters in alFatihah must be correct?" and the answer was "I know". From the results of the interview, it can be seen that in fact the students knew that reciting the letters in the al-Fatihah reading must be correct. When they have not mastered but rarely practice and follow the direction of the supervisor, this is a matter of responsibility and priority scale inherent in the student. Some of the students answered because they were nervous and tense if they were directly confronted by the lecturer. This answer showed that there was a lack of confidence due to the lack of courage from the students. However, if this was the reason, then this could be proven in the next test namely the practice of reading al- Qur'an, Surat al-Fatihah.

Next, a number of tests was conducted to measure the level of mastery of the hijaiyyah letters in the practice reciting surah al-Fatihah and then compared the results with the pretest results. The results of these tests are shown as follows. 


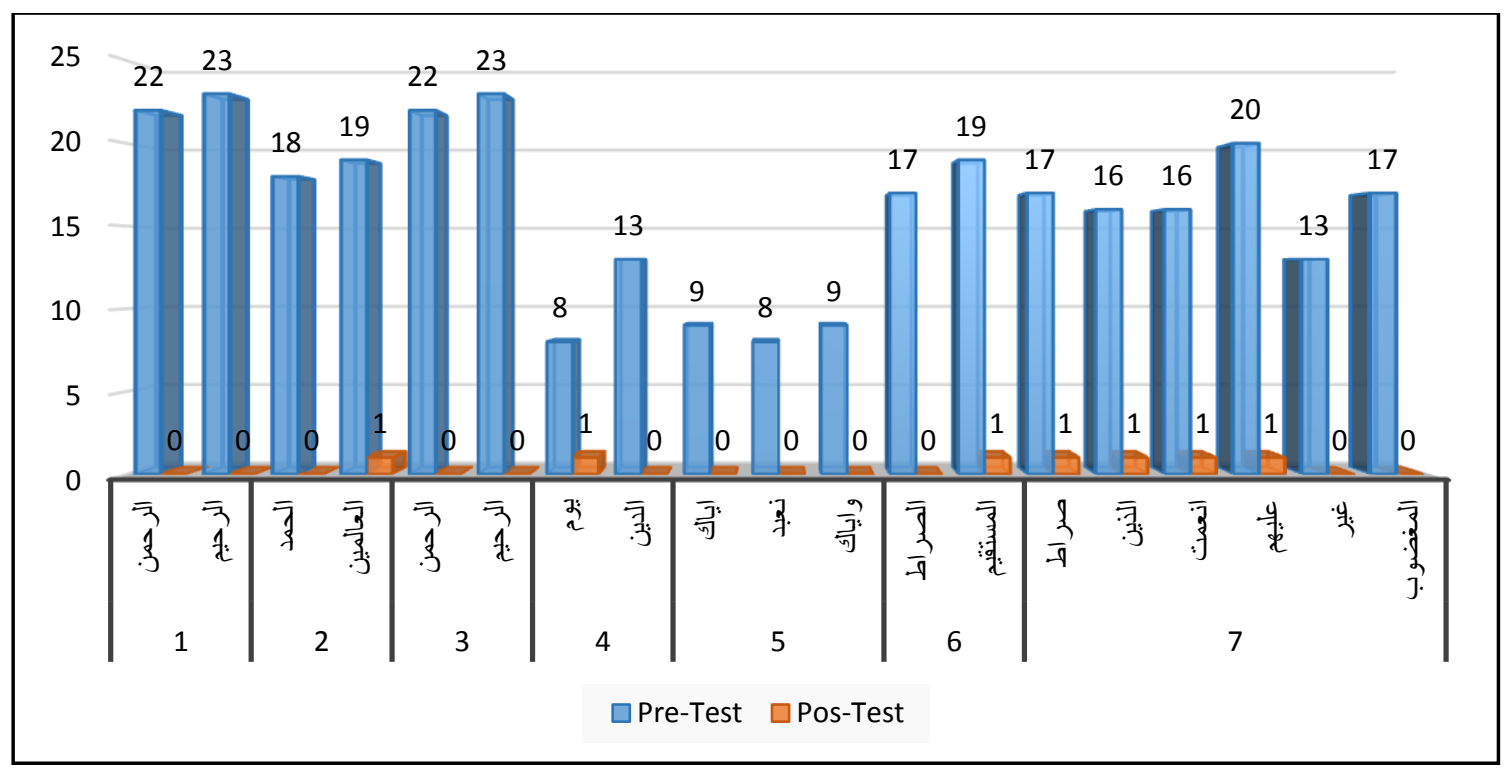

Figure 8. Evaluation Results of Reciting Surah Al-Fatihah

By comparing the results of the pre-test and post-test, the figure shows that there was a decrease in the number of interference in the pronunciation of hijaiyyah letters in reciting surah al-Fatihah. The results of the evaluation can be stated that most students had been able to recite Surah al-Fatihah properly and correctly in accordance with the rules of recitation. There were no longer forms of errors such as the results of the pretest in Table 6, both errors in the LahnJali and LahnKhafi categories. The learning outcome was that the students were able to reduce the number of errors in the pronunciation of the letters in reciting surah al-Fatihah. The decrease in the number of errors has an impact on the increase in abilities and skills in the practice of reading Surat al-Fatihah properly and correctly.

\subsection{Post Action Analysis and Evaluation}

The results of the developed actions on phonological interference problems in reciting Al-Qur'an were the successful reduction of the number of errors categorized as LahnJali and Lahn Khafi in the practice of reciting Surah alFatihah. Viewed from the results of the pre-test and post-test on students' accuracy in reciting surah Al-Fatihah, it can be described as follows. 


\section{E Tidak Tepat E Tepat}

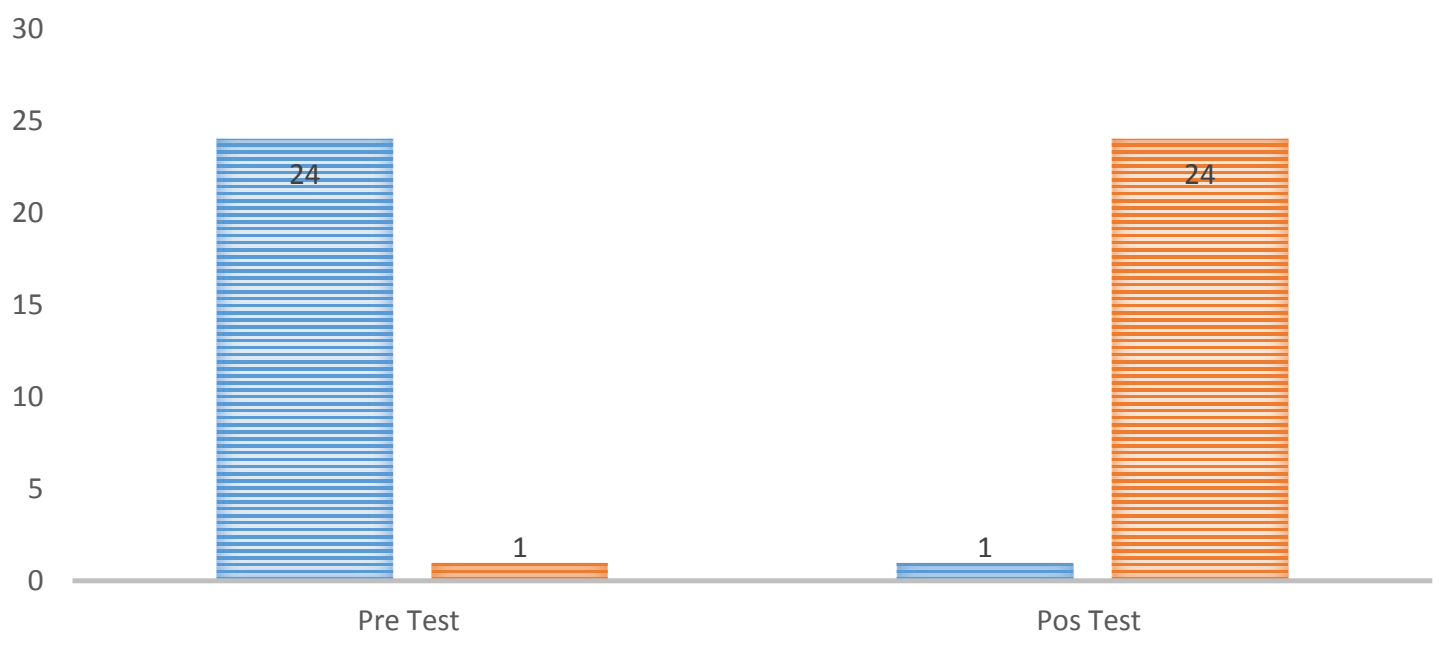

Figure 9. Comparison of Pretest and Posttest Results in Reciting Surah Al-Fatihah

The picture above shows the inverse comparison of the students' accuracy in reading Surah al-Fatihah. In the pretest, there was only 1 student or $(4 \%)$ who was correct in the recitation and the remaining 24 people or $96 \%$ were still incorrect. As for the posttest, there was only $1(4 \%)$ student who was still incorrect and the remaining 24 (96\%) students were correct. Therefore, the actions developed in an effort to resolve the phonological interference in reciting Al-Qur'an were able to reduce the number of interference errors by $96 \%$.

\section{Discussion}

This study results have provided a new understanding that Arabic consonant or vowel sounds in Al-Quran that are not found in Javanese can be produced by intensive training so that the pronunciation becomes precise. The process of practicing does not require a long time. It is true that a language spoken by someone with a different cultural background from the origin of the language itself will have interference in all components of the language, namely the sound, sentence order, word order, and meaning. However, this is not something that cannot be changed or corrected (Aslinda, 2007). In order to speak a language in accordance with the original language expression, an adaptation process is needed through intensive training and learning so that pronunciation is appropriate with how it is supposed to be spoken. Thus, sound, sentence order, word order, and meaning are maintained, especially in reciting the sentence or verses of Al-Qur'an, which are in Arabic, done by non-Arabs.

Similar to the Indonesians who have a variety of languages, historically, the Arabs as the first people to receive Al-Qur'an also do not have only one dialect in the language since the Arab people consist of many tribes. In the beginning, some of the verses of Al-Qur'an were revealed in the language (dialect) of the Quraysh tribe and the people from other tribes found it difficult to absorb and pronounce the lafaz of Al-Qur'an (Ulum, 2015, p. 151). With this difficulty, Allah gave permission to Muhammad to recite Al-Qur'an according to their language and dialect in order to make it easier. They were allowed to choose to recite Al- 
Qur'an with the dialect they like as long as the dialect does not change the meaning (Al-Shibagh, 1990, p. 171). This means that in the time of the Prophet, Al-Qur'an was pronounced using the dialect of each tribe as long as the meaning stays the same as in the dialect of Al-Qur'an when it was revealed. This phenomenon continues until many Arab societies write and are accustomed to the language of the Prophet while being able to recite it. When they are used to the language of the Prophet, they read Al-Qur' an according to what the Prophet delivered (Sinnah, 1995, p. 54).

In other words, it has been emphasized that fluency in reading Al-Qur'an not only can be achieved by native speakers of Arabic but also by non-native Arabic speakers and they can eloquently recite Al-Qur'an as long as they try to adapt to the language used by Al-Qur'an through the proper process of learning and instilled as early as possible. As the Prophet said in an hadith that we must teach our children three things, namely loving the Prophet, loving the family, and reciting Al-Qur'an (Sayuti, 1971, p.52). The social setting when the Prophet conveyed the messages was that it was delivered to the Arab community and since that it was permissible that Al-Qur'an was spoken with various dialects to facilitate the recitation. It can be understood that there were also possibilities of interference in reciting Al-Qur'an even with the Arabs. Yet with the professionalism and the Prophet's approach in educating his people, they were able to overcome the difficulties in reciting Al-Qur'an.

Based on the aforementioned matter, the problem of students' interference in reading Al-Qur'an, especially in reading Surah al-Fatihah, which is a surah that must be read by every Muslim in prayer and even an indicator of the validity of the prayer, clearly shows a lack of success in the previous learning process. One of the causes of unsuccessful teaching might be the teachers' habit of teaching unprofessionally, instantly, avoiding complication, and indifferent with the changes in the students. In fact, the teacher professional learning is a complex process, which requires cognitive and individual involvement, the capacity and willingness to examine where each one stands in terms of convictions and beliefs and the perusal and enactment of appropriate alternatives for improvement or change (Avalos, 2011). In this regard, teachers need to constantly reflect on themselves and strive to continue improving the quality of learning by understanding learning styles and teaching styles that can create a change in the learning process.

The teachers' ability to develop learning implies that teachers must also have literacy skills by exploring studies that can improve their abilities, for example how teacher learning is researched and propose or discuss models of teacher professional learning (Castle, 2006; James \& McCormick, 2009; Nisbet \& Shucksmith, 2017; Novak \& Gowin, 1984; Olson \& Craig, 2001). This is done as the teachers' effort to learn and change by developing theory or applying theory to the discussion of teacher change(Clarke \& Hollingsworth, 2002; Korthagen, 2010; Korthagen, 2004; Penlington, 2008). Therefore, as the results of this study show, teachers need to practice an action research approach in an effort to improve the quality of learning. 
Based on the elaboration, in an effort to minimize interference in the practice of reciting Al-Qur'an, studying the phonology of Al-Qur'an is a necessity for anyone who wants to learn and teach Al-Qur'an well, especially at the stage of learning to read Al-Qur'an. This is important to avoid mistakes in reading AlQur'an, so that every Muslim can recite Al-Qur'an in tartil which means that reciting Al-Qur'an is to read slowly with clear pronunciation of the letters, stopping, and continuing, so that readers and listeners can understand and appreciate the content of the messages (Katsir, 2000; Quraish Shihab, 2002).

\section{Conclusions}

This study has revealed the fact, that anyone with any cultural background will be able to fluently recite the letters and words in the sentence of Al-Quran as long as it is studied properly and correctly based on appropriate methods and strategies in the learning media used quite representative. This study resulted in several findings, after conducting the pre-test, 24 (96\%) students made phonological interference in reading Al-Fatihah classified into Lahn Jali (major) and $1(4 \%)$ of students classified into Lahn Kahfi (minor). The sound deviations in the practice of reading Al-Quran in Surah Al-Fatihah by the students are based on the use of Javanese language as a mother language, which were found in the letter $\tau$ to 5 , the sound a 'becomes nga, the letter $د$ becomes $ت$, the letter $\varepsilon$ ق becomes becomes 5 , letter $\varepsilon$ becomes I. In addition, other forms of sound deviation are

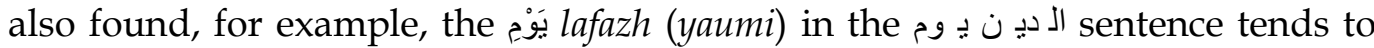
change the vowel sound ' $u$ ' into 'o', i.e. "yaomiddin" and the lafazh (ويَّر (ghairi) in the sentence المغضوب غٔير tend to change the vowel sound 'i' into 'o', i.e.

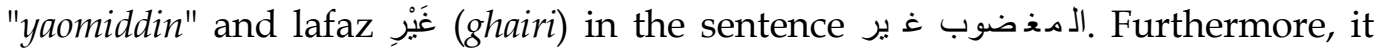
was also found a form of error in reducing tasydid in lafazh إيَآكَ to إيَّكَ

From these findings, there were five steps or stages in an effort to minimize interference. The five steps in this action research was called as the LOVVE method (L=Listening, $\mathrm{O}=$ Observation, $\mathrm{V}=$ Verification, $\mathrm{V}=$ Values, and $\mathrm{E}=$ Evaluation). Listening is carried out in the form of listening and documentation steps. Observation is carried out in the form the process of observation and mapping of errors in reading Al-Quran. Verification is carried out in an effort to develop teaching materials matched with the problems that occurred. Values is a learning process that develops educational values, and Evaluation is a series of final activities in an effort to measure the mastery of theory and ability to apply theory in the practice of reading Al-Quran. These five steps can be an alternative in developing the ability to read Al-Quran, and also have the opportunity to be developed further.

By using reflective-critical actions in the phonological learning of Al-Quran and the process of collaboration between researchers, colleagues, and students, this study activity has been able to produce a change in students who are not fluent in reading Al-Quran to become fluent in reading Al-Quran. These five action stages have been able to increase the fluency in reading Al-Quran by $96 \%$ or a number of 24 students from 25 students. Therefore, the action research conducted in this study can be an alternative solution for minimizing the occurrence of errors in reciting the reading of Al-Quran. 
Based on the results of this study, there are several recommendations for academics or practitioners, especially teachers as follows:

- In an effort to improve the ability to read Al-Quran fluently, a teacher needs to practice the action research approach in order to improve and polish the quality of learning.

- The findings in this study were the LOVVE method, in addition to this method as an alternative solution for improving fluency in reading AlQur'an and minimizing phonological interference, teacher skills support is also needed in developing innovative ICT-based teaching materials.

- With the many variety of languages in the world, especially those owned by the Indonesian people, the steps in this study can be used as a model for other researchers who have an interest in the same field, and can be developed by other researchers in solving phonological problems in the field of linguistic learning.

\section{Acknowledgment}

The authors extend their gratitude to the Universitas Pendidikan Indonesia for funding grants this study. The grant reference number is Decree of Rector of Universitas Pendidikan Indonesia No : 5493/UN40/KP/2019 dated 28 May 2019 with Research Contract No. 293/UN40.D/PP/2019.

\section{References}

Adelman, C. (1993). Kurt Lewin and the Origins of Action Research. Educational Action Research, 1(1), 7-24. doi:10.1080/0965079930010102

Adriana, I. (2017). Perubahan Bunyi Pada Bacaan-Bacaan Gharib dalam Alquran Menurut Tinjauan Fonologi Arab [Sound Changes in Gharib (Strange) Recitations in the Qur'an According to the Review of Arabic Phonology]. OKARA: Jurnal Bahasa dan Sastra, 11(1), 57-84. doi:10.19105/ojbs.v11i1.1238

Agus, D. (2011). Pembinaan dan Pengembangan Bahasa Daerah [Coaching and Development of Local Language]. In International Seminar Languange Maintenance and Shift. Semarang: Universitas Dipenogoro.

Aktürk-Drake, M. (2010). Phonological and sociolinguistic factors in the integration of/1/in Turkish in borrowings from Arabic and Swedish. Turkic Languages, 14(2), 153-191.

Al-Khuli, M. A. (1982). A dictionary of theoretical linguistics. Beirut: Librairie Du Liban.

Al-Malibari, Z. (2004). Fathul Muin [Opening Instruction of in Understanding Islamic Laws]. Surabaya, Salim Nabhan, tt.

Al-Shibagh, M. L. (1990). Lamhat fi Ulum al-Quran wa Ittijahat al-Tafsir [Exploring alQuran sciences toward today's interpretation]. Beirut: al-Maktab al-Islami.

Al Jaziri, A. (1994). Al Figh Alaa al Madzahibul Arba'ah [The Fiqh of Four Schools of Taught]. Lebanon: Darul Fikri.

Amrulloh, M. A. (2017). Kesamaan Bunyi pada Sajak (Kajian Fonologi al-Qur'an dalam Surat al 'Asar) [Similarity of Sound in Poetry (A Study on the phonology of alQur'an in Surah al 'Asar)]. Jurnal Al Bayan: Jurnal Jurusan Pendidikan Bahasa Arab, 9(1), 99-109. doi:10.24042/albayan.v9i1.1082

Aslinda, L. S. (2007). Pengantar sosiolinguistik [Introduction to Sociolinguistics]. Bandung: PT Refika Aditama.

Avalos, B. (2011). Teacher professional development in teaching and teacher education over ten years. Teaching and Teacher Education, 27(1), 10-20. 
doi:10.1016/j.tate.2010.08.007

Barron, B., \& Darling-Hammond, L. (2008). Teaching for Meaningful Learning: A Review of Research on Inquiry-Based and Cooperative Learning. Book Excerpt. George Lucas Educational Foundation.

Batmang, B. (2015). Kesalahan Fonologis dalam Berbicara Bahasa Arab pada Mahasiswa Matrikulasi STAIN Kendari [Phonological Mistakes in Speaking Arabic of Matriculation Students of Kendari Institute of Islamic Studies]. Al-Izzah: Jurnal Hasil-Hasil Penelitian, 8(1), 19-38.

Bukhori, M. bin I. bin M. Al. (1992). Shahih Al Bukhari [Authentic Hadith (Sayings) According to Al-Bukhari]. Beirut Libanon: Darul Qurub.

Capobianco, B. M., \& Feldman, A. (2006). Promoting quality for teacher action research: lessons learned from science teachers' action research. Educational Action Research, 14(4), 497-512. doi:10.1080/09650790600975668

Castle, K. (2006). Autonomy through pedagogical research. Teaching and Teacher Education, 22(8), 1094-1103. doi:10.1016/j.tate.2006.07.001

Clarke, D., \& Hollingsworth, H. (2002). Elaborating a model of teacher professional growth. Teaching and Teacher Education, 18(8), 947-967. doi : 10.1016/s0742051x(02)00053-7

Creswell, J. W. (2002). Educational research: Planning, conducting, and evaluating quantitative. Prentice Hall Upper Saddle River, NJ.

Crystal, D. (1992). Encyclopedia of Language. Oxford: Oxford press.

Dalby, A. (2015). Dictionary of languages: the definitive reference to more than 400 languages. Bloomsbury Publishing.

Darwis, R. S. (2016). Membangun Desain dan Model Action Research dalamStudi dan Aksi Pemberdayaan Masyarakat [Creating Design and Model of Action Research in Study and Action of Society Empowerment]. KOMUNIKA, 10(1), 142-153. doi:10.24090/komunika.v10i1.869

Departemen Agama, R. I. [The Department of Religious Affairs of the Republic of Indonesia]. (2005). Al-Quran dan Terjemahannya[Al-Quran and Its Translation]. Bandung: CV Penerbit J-Art.

Fraenkel, J. R., \& Wallen., N. E. (1990). How to Design and Evaluate Research in Education ( $7^{\text {th }}$ Edition). New York: McGraw-Hill Publishing Company.

Hamzah, K., \& Busri, H. (2015). Interferensi Fonologis Jawa-Sunda Masyarakat Kedungreja Cilacap Pada Penuturan Bahasa Arab. [Java-Sundanese Phonological Interference of the People of Kedungreja Cilacap in Speaking Arabic] Lisanul'Arab: Journal of Arabic Learning and Teaching, 4(1).

James, M., \& McCormick, R. (2009). Teachers learning how to learn. Teaching and Teacher Education, 25(7), 973-982. doi:10.1016/j.tate.2009.02.023

Jefferson, R. N. (2014). Action Research: Theory and Applications. New Review of Academic Librarianship, 20(2), 91-116. doi:10.1080/13614533.2014.921536

Katsir, I. (2000). Tafsir Ibnu Katsir [Al-Qur'an Interpretation by Ibnu Katsir]. Mesir: Dar al Kutub.

Khasanah, K., \& Qosim, M. N. (2017). Wacana Sosiofonologis Pelafalan Huruf/ع/dalam huruf Hijaiyah pada Masyarakat Jawa [Sociophonological Discourse of / / / Prnonunciation in Hijaiyyah Letter in Javanese People]. URECOL, 323-332.

Korthagen, F. A. J. (2010). Situated learning theory and the pedagogy of teacher education: Towards an integrative view of teacher behavior and teacher learning. Teaching and Teacher Education, 26(1), 98-106. doi:10.1016/j.tate.2009.05.001

Korthagen, F. A. J. (2004). In search of the essence of a good teacher: towards a more 
holistic approach in teacher education. Teaching and Teacher Education, 20(1), 7797. doi:10.1016/j.tate.2003.10.002

Lathifah, F., Syihabuddin, S., \& Al Farisi, M. (2018). Analisis Kesalahan Fonologis Dalam Keterampilan Membaca Teks Bahasa Arab [Analysis of Phonolocal Mistakes in Arabic Text Reading Skills. Arabiyat: Jurnal Pendidikan Bahasa Arab dan Kebahasaaraban, 4(2), 174-184. doi:10.15408/a.v4i2.6273

Lodge, K. (2003). Phonological translation and phonetic repertoire. International Journal of Applied Linguistics, 13(2), 263-276. doi: 10.1111/1473-4192.00047

Messiou, K. (2019). Collaborative action research: facilitating inclusion in schools. Educational Action Research, 27(2), 1-13. doi: 10.1080/09650792.2018.1436081

Moon, K., Brewer, T. D., Januchowski-Hartley, S. R., Adams, V. M., \& Blackman D. A. (2016). A guideline to improve qualitative social science publishing in ecology and conservation journals. Ecology and Society, 21(3), 17. doi:10.5751/ ES-08663210317

Mu'izzuddin, M. (2002). Analisis Fonologi Bahasa Arab [Analysis of Arabics Phonology]. Al-Qolam, 19(3), 67-90. doi:10.32678/alqalam.v19i93.455

Nasution, S. (2017). Pengantar Linguistik Bahasa Arab [Introduction of the Lingustics of Arabics]. Sidoarjo: Lisan Arabi.

Niemi, R. (2018). Five approaches to pedagogical action research. Educational Action Research, n.v, 1-16. doi:10.1080/09650792.2018.1528876

Nisbet, J., \& Shucksmith, J. (2017). Learning strategies. UK, London: Routledge. doi:10.4324/9781315188652

Nokman, A. Z., Mat, A. C., Bakar, A. F. A., Musilehat, N. S., \& Yaakub, A. N. M. (2017). A Study on The First-Language Influence on The Arabic Pronunciation among Terengganuians in Malaysia. International Journal of Applied Linguistics and English Literature, 6(4), 76-80. doi:10.7575/aiac.ijalel.v.6n.4p.76

Novak, J. D., \& Gowin, D. B. (1984). Learning how to learn. Cambridge University Press.

Olson, M. R., \& Craig, C. J. (2001). Opportunities and challenges in the development of teachers' knowledge: The development of narrative authority through knowledge communities. Teaching and Teacher Education, 17(6), 667-684. doi:10.1016/s0742-051x(01)00023-3

Pansuri, H. (2017). Interferensi Fonologis Penutur Indonesia Berbahasa Arab dan Sebaliknya [Phonological Interference of Indonesian People Speaking Arabics and Vice Versa]. Al-Ihda', 12(1), 1-20.

Penlington, C. (2008). Dialogue as a catalyst for teacher change: A conceptual analysis. Teaching and Teacher Education, 24(5), 1304-1316. doi:10.1016/j.tate.2007.06.004

Saavedra, A. R., \& Opfer, V. D. (2012). Teaching and learning 21st century skills: Lessons from the learning sciences. Retrieved August, 1, 2016.

Sai, Y. (2018). Teaching Qur'an in Irish Muslim schools--curriculum, approaches, perspectives and implications. British Journal of Religious Education, 40(2), 148157. doi:10.1080/01416200.2016.1269723

Sayuti, A. (1971). Jalaluddin Abdul Rahman Bin Abu Bakar. Al Jami'us Shagir Juz 1 [Hadith Dictionary]. Beirut: Darul Fikr.

Shihab, Q. (1992). Membumikan al-Quran, Fungsi dan Peran Wahyu dalam Kehidupan Masyarakat [Earthing Al-Qur'an, Function and Role of Revelation in Society Life]. Bandung: Mizan.

Shihab, M. Q. (2002). Tafsir Al-Misbah. Pesan, Kesan dan Keserasian Al Qur'an.[Al-Misbah Interpretation. Message, Impression, and the Harmony with Al-Qur'am Jakarta: Lentera Hati.Sinnah, A. al-F. A. (1995). Ulum al-Quran [Science of Al-Qur'an]. Kairo: Dar al-Syaruq. 
Suherman, A. (2016). Perubahan Fonologis Kata-kata Serapan Bahasa Sunda dari Bahasa Arab: Studi Kasus pada Masyarakat Sunda di Jawa Barat, Indonesia [Phonological Changes of Sundanese Language Absorption Wods from Arabic Language: Case Study of Sundanese People in West Java ]. SOSIOHUMANIKA, $5(1)$.

Supriyadi, T., \& Julia, J. (2019). The Problem of Students in Reading the Quran: A Reflective-Critical Treatment through Action Research. International Journal of Instruction, 12(1), 311-326. doi:10.29333/iji.2019.12121a

Surat Keputusan Bersama Menteri Agama dan Menteri Pendidikan dan Kebudayaan Republik Indonesia [Joint Decree of Minister of Religious Affair and Ministry of Education and Culture of the Republic of Indonesia] No. 158 Tahun 1987 dan Nomor: 0543b/U/1987

Taufiqurrochman, T. (2007). Fenomena Lahn dalam Ritual Ibadah [Phenomenon of Lahn in Praying Ritual]. El Harakah, 9(2), 165. doi:10.18860/el.v9i2.4653

Ulum, K. (2015). Dialek dan Bacaan dalam Al-Quran: Mengurai Perbedaan Antara Sab'ah Ahruf dan Qira'ah Sab'ah [Dialect and Reading in Al-Qur'an: Unravelling the Difference between Sab'ah Ahruf and Qira'ah Sab'ah]. Al Hikmah: Jurnal Studi Keislaman, 5(2).

Utsman, H. S. (1994). Haqqu At-Tilawah [Rights in Reading Al-Qur'an]. Jeddah: Daar elManarah.

Wakaf, K., \& Kuwait, U. A. (1986). Al-Mausu'ah al-fighiyyah al-kuwaitiyyah [Encyclopedia of Fiqh]. Kuwait: Dar al-Salasil.

Wedhawati, Wiwin, E. S. N., Edi, S., Marsono, Restu, S., \& Baryadi, I. P. (2006). Tata Bahasa Jawa Mutakhir [Current Grammar of Javanese Language]. Yogyakarta: Kanisius.

Weinreich, U. (1979). Languages in contact: Findings and problems. Walter de Gruyter.

Wikipedia. (2018). Daftar bahasa menurut jumlah penutur asli [List of languages according to numbers of native speakers]. Retrieved May 2, 2018, from https://id.wikipedia.org/wiki/Daftar_bahasa_menurut_jumlah_penutur_asli

Zech, L. K., Gause-Vega, C. L., Bray, M. H., Secules, T., \& Goldman, S. R. (2000). ContentBased Collaborative Inquiry: A Professional Development Model for Sustaining Educational Reform. Educational Psychologist, 35(3), 207-217. doi:10.1207/S15326985EP3503_6 